(C) 2020, The Authors. Published by FASS Inc. and Elsevier Inc. on behalf of the American Dairy Science Association ${ }^{\circledR}$. This is an open access article under the CC BY-NC-ND license (http://creativecommons.org/licenses/by-nc-nd/4.0/).

\title{
Contrasting effects of transforming growth factor $\beta 1$ on programmed cell death of bovine mammary epithelial cell lines MAC-T and BME-UV1
}

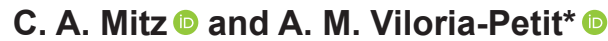

Department of Biomedical Sciences, Ontario Veterinary College, University of Guelph, 50 Stone Road East, Guelph, ON, N1G 2W1, Canada

\section{ABSTRACT}

A previous study in the bovine mammary epithelial cell line BME-UV1 demonstrated that suppression of the phosphatidylinositol-4,5-biphosphate 3 kinase (PI3K)/AKT (somatotropic) signaling pathway was required for transforming growth factor $\beta 1$ (TGF $\beta 1$ ) induced programmed cell death (PCD). To investigate whether this is a universal mechanism for TGF $\beta 1$ to induce PCD in bovine mammary epithelium, we compared TGF $\beta 1$ modulation of PI3K/AKT and its role in PCD in 2 bovine mammary epithelial cell lines: MAC-T and BME-UV1. In MAC-T cells, TGF $\beta 1$ promoted cell survival, and this paralleled a reduction in PI3K/AKT activity, rather than an increase. In BME-UV1 cells, TGF $\beta 1$ induced PCD, and this was accompanied by a time-dependent effect on PI3K/AKT activity, including an initial significant increase in the phosphorylation of AKT at $3 \mathrm{~h}$, followed by a reduction between 12 and $24 \mathrm{~h}$, and then an increase at $48 \mathrm{~h}$. Inhibition of AKT activity enhanced TGF $\beta 1$-induced PCD in BME-UV1 cells but had no effect on MAC-T cells, suggesting that TGF 31 mediates PCD in BME-UV1 cells through suppression of AKT activity. Inhibition of TGF $\beta$ receptor type I (T $\beta R I)$ kinase activity completely abrogated TGF 31 -induced PCD in BME-UV1 cells but had no effect on TGF $\beta 1$-induced suppression of PCD in MAC$\mathrm{T}$ cells, demonstrating that TGF $\beta 1$-induced PCD in BME-UV1 cells is dependent on T $\beta R I / S M A D$ signaling. These and previous observations suggest that the different effects of TGF $\beta 1$ on PCD in these cell lines might involve noncanonical signaling pathways other than PI3K/AKT, and may reflect their different lineages. Future studies should address this finding, taking into consideration the effect that different culture conditions might have on cell phenotype.

Key words: transforming growth factor $\beta 1$ (TGF $\beta 1$ ), programmed cell death, MAC-T, BME-UV1, PI3K/ AKT

Received August 22, 2019.

Accepted January 17, 2020.

*Corresponding author: aviloria@uoguelph.ca

\section{INTRODUCTION}

Exogenous administration of growth hormone is one of the ways dairy farmers increase lactation persistency (Etherton and Bauman, 1998). Growth hormone is considered to be the predominant galactopoietic hormone in dairy cows (Tucker, 2000) and can enhance milk production by 10 to $15 \%$ by increasing mammary cell numbers (somatogenic effects) and mammary secretory cell activity (metabolic effects; Etherton and Bauman, 1998). Insulin-like growth factor I mediates many of the galactopoietic effects of growth hormone (Bauman, 1999). Binding of IGF-I to the IGF receptor initiates its intrinsic tyrosine kinase activity and leads to the activation of the phophatidylinositol-4,5-biphosphate 3 kinase (PI3K)/AKT pathway (Argetsinger et al., 1993). In this article, we refer to the growth hormoneIGF-I-PI3K-AKT signaling axis as the somatotropic pathway. One of the ways that the somatotropic axis enhances survival of bovine mammary epithelial cells is through suppression of the cytokine transforming growth factor $\beta 1$ (TGF $\beta 1$; Gajewska and Motyl, 2004).

Transforming growth factor $\beta 1$ and its receptors are upregulated during bovine mammary gland involution (Plath et al., 1997; Finot et al., 2019), a process by which the mammary gland transitions from a lactating to a nonlactating state (Hurley, 1989). Transforming growth factor $\beta 1$ plays a key role in bovine mammary gland involution by inducing programmed cell death (PCD) and growth arrest in bovine mammary epithelial cells (Kolek et al., 2003; Zarzyńska et al., 2005). It is thought that elevated TGF $\beta 1$ expression during involution is due in part to its increased secretion by bovine mammary cells during the transition from lactation to the dry period (Zarzyńska et al., 2005). Gajewska and Motyl (2004) found that suppression of the PI3K/AKT signaling pathway was involved in the apoptotic response to TGF $\beta 1$ in the normal bovine mammary epithelial cell line BME-UV1. In BME-UV1 cells, TGF $\beta 1$ increased the expression of IGF binding proteins 3 and 4, which led to the sequestration of IGFI from the IGF-I receptor, reduction of PI3K/AKT signaling, and increased expression of the pro-apoptotic protein Bcl-2-associated death promoter (BAD), which 
is a downstream target of PI3K/AKT (Gajewska and Motyl, 2004). In addition, exogenous IGF-I administration to BME-UV1 cells completely blocked PCD and autocrine TGFß1 expression under low serum conditions, and this effect was reversed with a PI3K inhibitor (Zarzyńska and Motyl, 2005). Together with the previous study (Gajewska and Motyl, 2004), these results support the notion that TGF $\beta 1$-induced PCD of BME-UV1 cells is mediated through suppression of the somatotropic pathway.

The MAC-T cell line is an immortalized bovine mammary epithelial cell line that has been used extensively to study signaling pathways involved in mammary epithelial growth regulation and milk protein gene expression (Jedrzejczak and Szatkowska, 2014). We recently reviewed the literature on MAC-T and BME-UV1 cell lines in the context of bovine mammary gland biology and TGF $\beta 1$ signaling (Mitz and Viloria-Petit, 2019). Interestingly, we found no reports to demonstrate that exogenous TGF $\beta 1$ induces PCD or suppresses the somatotropic pathway in MAC-T cells. Further, lineage marker characterization in MAC-T and BME-UV1 cells suggests that MAC-T cells and BME-UV1 cell lines might have different origins, possibly explaining their different responses to hormones and growth factors. Reports have shown that MAC-T cells encompass a heterogeneous population that includes ductal-like and myoepithelial-like cell types, and generate both luminal and myoepithelial cells when transplanted into murine mammary fat pads; BME-UV1 cells, on the other hand, express luminal markers, in addition to CD10 (Maspin) and aldehyde dehydrogenase, suggesting an enrichment of luminal progenitor cells in BME-UV1 (reviewed in Mitz and Viloria-Petit, 2019).

To further our understanding of these cell lines and their applicability to studies of bovine mammary gland biology, here we compared their PCD and growth response to TGF $\beta 1$ in relation to $\mathrm{PI} 3 \mathrm{~K} / \mathrm{AKT}$ activity. We hypothesized that TGF $\beta 1$-induced changes in PI3K/AKT and downstream signaling mediators would reflect the role of PI3K/AKT in cell survival and growth and correlate with cell death and growth arrest in both the MAC-T and BME-UV1 cell lines. However, our evidence suggested that the effect of TGF $\beta 1$ on PCD in these cell lines does not necessarily correspond to observed changes in PI3K/AKT signaling induced by this growth factor.

\section{MATERIALS AND METHODS}

\section{Cell Lines and Culture Conditions}

The MAC-T cell line is an immortalized epithelial cell line derived from the bovine mammary gland by
Huynh et al. (1991), and was provided to us by Bonnie Mallard (Department of Pathobiology, University of Guelph, Guelph, ON, Canada). The MAC-T cells were grown as a monolayer in HyClone Dulbecco's modified Eagle medium/high glucose medium (Sigma Aldrich, Oakville, ON, Canada) supplemented with $10 \%$ fetal bovine serum (FBS; VWR, Mississauga, ON, Canada) at $37^{\circ} \mathrm{C}$ in $5 \% \mathrm{CO}_{2}$ and $95 \%$ atmospheric air in a humid environment. The medium contained the antibiotics gentamicin (Fisher Scientific, Ottawa, ON, Canada) at $50 \mu \mathrm{g} / \mathrm{mL}$, and penicillin and streptomycin (HyClone; Sigma Aldrich) at $100 \mathrm{U} / \mathrm{mL}$ and $100 \mu \mathrm{g} / \mathrm{mL}$, respectively.

The BME-UV1 cell line was purchased from Instituto di Alimentazione Animale, Facoltà di Medicina Veterinaria (Milan, Italy). The optimal growth conditions for these cells were determined by Zavizion et al. (1996) and included a mix of media composed of $40 \% \mathrm{HyClone}$ Ham's nutrient mixture F12, 30\% HyClone RPMI 1640 (both from Fisher Scientific), and 20\% NCTC 135 (Sigma Aldrich). This mix was supplemented with $10 \%$ FBS, 0.1\% lactose (Sigma Aldrich), 0.1\% lactalbumin hydrolysate (Sigma Aldrich), $1.2 \mathrm{~m} M$ glutathione (Sigma Aldrich), $10 \mu \mathrm{g} / \mathrm{mL}$ L-ascorbic acid (Sigma Aldrich), $1 \mu \mathrm{g} / \mathrm{mL}$ hydrocortisone (Sigma Aldrich), and $1 \mu \mathrm{g} / \mathrm{mL}$ insulin (Sigma Aldrich). In addition to the antibiotics added to MAC-T cell line, the BME-UV1 medium contained $2.5 \mu \mathrm{g} / \mathrm{mL}$ amphotericin B (Fisher Scientific).

Both cell lines were passaged, or plated for an experiment, when $80 \%$ confluence was reached, and all experiments were conducted using starve medium (the specific basal medium for each cell line plus $0.2 \%$ FBS plus antibiotics). Different growth conditions for MAC-T and BME-UV1 cells before experimentation, and their different basal media are important factors to consider when examining the effects of TGF $\beta 1$ on these cell lines; supplementation with additional growth factors in the case of BME-UV1 might provide an environment more similar to the actual mammary gland.

\section{Antibodies, Inhibitors, and Growth Factors}

Primary antibodies from Cell Signaling Technologies (Danvers, MA) included pan-AKT (\#4961, 1:10,000), $\beta$-actin (\#4967, 1:5,000), Bcl-2 interacting mediator of cell death (BIM; \#2933, 1:1,000), cleaved caspase 3 (CC3; \#9661, 1:1,000), forkhead box O 1 (FOXO1; \#2880, 1:1,000) and pan phospho-AKT Ser473 (\#4060, 1:4,000). Primary antibodies from Abcam (Cambridge, MA) included phospho-histone H3 Ser10 (pHH3; \#ab5176, 1:10,000 and 1:1,000 for BME-UV1 and MAC-T, respectively), phospho-SMAD3 Ser423/425 (\#ab52903, 1:2,000), and SMAD3 (\#ab28379, 1:2,000). 
Secondary antibodies obtained from Sigma Aldrich and Life Technologies (Burlington, ON, Canada) included peroxidase-conjugated goat anti-rabbit (\#A0545, 1:10,000) and Alexa Fluor donkey anti-rabbit 488 (\#A21206, 1:500).

Recombinant human TGF $\beta 1$ protein (R\&D Systems, Minneapolis, MN) was used at a concentration of 5 $\mathrm{ng} / \mathrm{mL}$. The T $\beta R I$ inhibitor LY2157299 (LY) was obtained from Cayman Chemical (Ann Arbor, MI) and used at a concentration of $5 \mu M$. Pan-AKT was inhibited using the AKT-specific inhibitor MK-2206 (MK; Selleckchem, Houston, TX) at $0.625 \mu M$. Both LY and MK were previously tested at several different concentrations to determine the dose that caused maximal inhibition of SMAD and AKT, respectively, without affecting total levels of the target proteins.

\section{Protein Preparation and Quantification}

Lysis buffer composed of $20 \mathrm{~m} M$ Tris hydrochloride (pH 7.5), $150 \mathrm{~m} M$ sodium chloride, $1 \mathrm{~m} M$ EDTA disodium salt, $1 \mathrm{~m} M$ EGTA, $1 \%$ triton, $2.5 \mathrm{~m} M$ sodium pyrophosphate, $1 \mathrm{~m} M \beta$-glycerolphosphate, $1 \mathrm{~m} M$ sodium orthovanadate, and $1 \mu \mathrm{g} / \mathrm{mL}$ leupeptin was created by diluting a $10 \times$ stock (Cell Signaling) in milliQ water. This buffer was supplemented with $1 \mathrm{~m} M$ phenylmethylsulfonyl fluoride (Sigma Aldrich), $2 \mu \mathrm{g} / \mathrm{mL}$ aprotinin (Sigma Aldrich), 1\% phosphatase inhibitor cocktail (Sigma Aldrich), and $1 \mathrm{~m} M$ sodium orthovanadate (New England BioLabs, Whitby, ON, Canada). To lyse the floating cell fraction, medium from each plate was collected and placed in a $15-\mathrm{mL}$ conical tube (Sarstedt, Nümbrecht, Germany), which was then centrifuged for 20 min at $800 \times g$ and $4^{\circ} \mathrm{C}$ using a Sorvall Legend XT/ XF Centrifuge (Fisher Scientific). After centrifugation, the cell pellet was resuspended in $20 \mu \mathrm{L}$ of lysis buffer, and then transferred to a $1.5-\mathrm{mL}$ microcentrifuge tube (Fisher Scientific). For adherent cells, lysis buffer was added to each plate: $50 \mu \mathrm{L}$ or $100 \mu \mathrm{L}$ to 60 - or 100 mm plates, respectively. Following a 5-min incubation with lysis buffer, cell scrapers (Sarstedt) were used to collect lysate, which was then transferred to the corresponding $1.5-\mathrm{mL}$ microcentrifuge tube containing the floating cell fraction and kept on ice. Cells were left on ice to continue lysing for an additional $30 \mathrm{~min}$, mixing by inversion every $5 \mathrm{~min}$. Lysates were then centrifuged for $20 \mathrm{~min}$ at $25,000 \times g$ and $4^{\circ} \mathrm{C}$ using a Sorvall Legend XT/XF Centrifuge (Fisher Scientific). The supernatant containing total cellular protein was transferred to a new microcentrifuge tube and stored at $-80^{\circ} \mathrm{C}$ until use. Protein concentration was measured using the Bio-Rad protein assay kit (Bio-Rad, Mississauga, ON, Canada), following the manufacturer's instructions (https://www.bio-rad.com/webroot/web/ pdf/lsr/literature/4110065A.pdf).

\section{Immunoblotting}

Total cellular lysate was combined with milliQ water and loading buffer. The amount of lysate loaded into the gel varied depending on the protein being evaluated. These protein samples were then denatured by heating for $5 \mathrm{~min}$ at $95^{\circ} \mathrm{C}$, followed by pulse centrifugation before their loading into 10 or $12 \%$ SDS-polyacrylamide gels (Bio-Rad). Proteins were separated via electrophoresis $(120 \mathrm{~V})$ under denaturing conditions in a Mini-Protean Tetra Cell using a PowerPac HC Power Supply (both from Bio-Rad).

Following separation, protein was electrophoretically transferred to a polyvinylidene difluoride membrane (Roche, Laval, QC, Canada). The transfer was completed under wet conditions using a Mini Trans-Blot module (Bio-Rad), or semi-dry conditions using a Trans-Blot SD semi-dry electrophoretic transfer cell (Bio-Rad), for $2 \mathrm{~h}$ at $100 \mathrm{~V}$ or $30 \mathrm{~min}$ at $17 \mathrm{~V}$, respectively. Following transfer, the polyvinylidene difluoride membranes were briefly rinsed with Tris buffer saline containing 0.1\% tween (TBST; Fisher Scientific) before blocking for $1 \mathrm{~h}$ in $5 \%$ nonfat milk or $5 \%$ BSA diluted in TBST. Membranes were then incubated overnight with primary antibody diluted in the appropriate blocking solution, rocking at $4^{\circ} \mathrm{C}$. Following overnight incubation with primary antibody, membranes were washed 3 times for 10 min each with TBST, followed by the addition of secondary antibody. Membranes were incubated in secondary antibody conjugated with horseradish peroxidase at room temperature for $1 \mathrm{~h}$. Following this, membranes were washed 3 times for $10 \mathrm{~min}$ each with TBST and exposed to the chemiluminescent substrate Luminata Forte (Millipore, Etobicoke, ON, Canada), for 2 min. Light emitted was detected with a ChemiDoc gel imaging system (Bio-Rad), and bands were quantified using Image Lab software (Bio-Rad). Relative phosphorylation levels were then generated by normalizing with corresponding total protein levels. Total protein levels were normalized with the loading control ( $\beta$-actin). Relative phosphorylation and protein levels were compared between the treatment and the corresponding control for each time point.

\section{Annexin V/Propidium lodide PCD Assay}

The MAC-T and BME-UV1 cells were trypsinized, counted, resuspended in their growth media, and plated into $60-\mathrm{mm}$ plates at densities of 500,000 and 850,000 cells per dish, respectively. Cells were allowed to grow 
for $1 \mathrm{~d}$ and then starved for $16 \mathrm{~h}$ in basal medium containing $0.2 \% \mathrm{FBS}$ at approximately $80 \%$ confluency. The starve medium was then aspirated, and the cells were treated with $5 \mathrm{ng} / \mathrm{mL}$ of TGF $\beta 1$ for $48 \mathrm{~h}$, or control media. Treatment groups included a TGF $\beta 1$-treated and -untreated control dish, which was stained with annexin $\mathrm{V}$ and propidium iodide (PI). Four additional dishes included single-stain controls (stained with only annexin V or only PI), an unstained control, and a positive control for cell death treated with etoposide (Sigma Aldrich) at a concentration of $50 \mu M$. Following $48 \mathrm{~h}$ of treatment under standard incubation conditions, both adherent and floating cells were collected. For this purpose, the medium was collected from each treatment group and placed in a $15-\mathrm{mL}$ tube. Adherent cells were detached via trypsinization and added to the corresponding $15-\mathrm{mL}$ tube, which was then spun down at $400 \times g$ for $20 \mathrm{~min}$ at $4^{\circ} \mathrm{C}$. The resulting cell pellet was resuspended in $1 \mathrm{~mL}$ of PBS, and the cell suspension was spun down at $400 \times g$ for 5 min at $4^{\circ} \mathrm{C}$. After this point, all work was performed in the dark using reagents provided by the annexin V-FITC Apoptosis Detection kit (Biotool, Burlington, ON, Canada), as follows. After discarding the supernatant, the cell pellet was resuspended in $100 \mu \mathrm{L}$ of $1 \times$ binding buffer. Then, $5 \mu \mathrm{L}$ of annexin V-fluorescein isothiocyanate (FITC) and $5 \mu \mathrm{L}$ of PI staining solution were added to each tube and allowed to incubate for $15 \mathrm{~min}$ at room temperature. An additional $400 \mu \mathrm{L}$ of $1 \times$ binding buffer was added and mixed gently on ice. Samples were then filtered through a 100- $\mu \mathrm{m}$ cell strainer (VWR) before analysis, which was carried out in a BD Accuri C6 flow cytometer (BD Biosciences, Mississauga, ON, Canada), set for analysis of 50,000 cells at slow speed.

\section{Cell Cycle Analysis}

The MAC-T and BME-UV1 cells were seeded at densities of 500,000 and 850,000 cells, respectively, in $60 \mathrm{~mm}$ plates and allowed to grow for $1 \mathrm{~d}$ before being starved in their basal medium containing $0.2 \%$ FBS for $16 \mathrm{~h}$. Following starvation, cells were treated with $5 \mathrm{ng} /$ $\mathrm{mL}$ of TGF $\beta 1$ for $48 \mathrm{~h}$ or untreated (control media). At this point, cells were trypsinized, passed through a syringe, and filtered through a $100-\mu \mathrm{m}$ cell strainer to obtain a single cell suspension, which was centrifuged for $5 \mathrm{~min}$ at $200 \times \mathrm{g}$ and $4^{\circ} \mathrm{C}$ using a Sorvall Legend $\mathrm{XT} / \mathrm{XF}$ centrifuge (Fisher Scientific) and then washed with $1 \mathrm{~mL}$ of PBS. The centrifugation was repeated and cells were resuspended in $1 \mathrm{~mL}$ of PBS and fixed with $9 \mathrm{~mL}$ of $70 \%$ ethanol. Fixed cells were stored at $4^{\circ} \mathrm{C}$ until use, when they were centrifuged for 5 min at $200 \times g$ and $4^{\circ} \mathrm{C}$ to remove the fixative and washed twice with $1 \mathrm{~mL}$ of PBS. Cells were resuspended in 0.5
$\mathrm{mL}$ of FxCycle PI/RNase staining solution (Fisher Scientific) and incubated for $30 \mathrm{~min}$ at room temperature before analysis with the $\mathrm{BD}$ Accuri C6 flow cytometer (BD Biosciences) software. The gated population was plotted as a frequency histogram with PI on the x-axis. The DNA content measurements of individual cells provided information about their ploidy, or the number of sets of chromosomes contained in an individual cell (i.e., haploid, diploid, or tetraploid), and this was used to categorize cell cycle phases $\left(G_{0} / G_{1}, S\right.$, and $\left.G_{2} / M\right)$.

\section{Phospho-Histone H3 Immunofluorescence}

The MAC-T and BME-UV1 cells were plated at a density of 30,000 and 50,000 cells/well, respectively, in 8-well chamber slides (VWR). Cells were allowed to grow for $1 \mathrm{~d}$ and then starved for $16 \mathrm{~h}$ in basal medium containing $0.2 \%$ FBS. At this time, cells were treated with $5 \mathrm{ng} / \mathrm{mL}$ of TGF $\beta 1$ for $48 \mathrm{~h}$ or untreated (control). After this, cells were washed with PBS and fixed using $4 \%$ paraformaldehyde (EMS, Hatfield, PA) in PBS for $20 \mathrm{~min}$ at room temperature. Next, cells were washed 4 times with PBS, and the fourth wash was left on the cells for storage at $4^{\circ} \mathrm{C}$ until immunofluorescence was carried out. Before immunofluorescent staining, the PBS was removed from the cells, and they were permeabilized with $0.5 \%$ Triton-X 100 (Fisher Scientific) in PBS for $10 \mathrm{~min}$ at $4^{\circ} \mathrm{C}$. Cells were washed 3 times for 2 min each time with PBS, and blocked with PBS containing 5\% normal donkey serum (NDS; Sigma Aldrich) for $1 \mathrm{~h}$ at room temperature. Cells were next incubated with primary antibody for $\mathrm{pHH} 3$ (Abcam) diluted in PBS containing 5\% NDS for $16 \mathrm{~h}$ at $4^{\circ} \mathrm{C}$. Cells were washed 3 times for 2 min each time with PBS, and the Alexa Fluor donkey anti-rabbit 488 (Life Technologies) was then added to the cells at a dilution of 1:500 in PBS containing 5\% NDS for $1 \mathrm{~h}$ at room temperature. Three PBS washes followed. To visualize cell nuclei, cells were incubated with $0.3 \mu M$ 4',6-diamidino-2-phenylindole (DAPI; Sigma Aldrich) diluted in PBS for $5 \mathrm{~min}$ at room temperature. This was followed by a washing step. Following aspiration of this last wash, the slides were coverslipped using Dako fluorescence mounting medium (Dako, Burlington, ON, Canada). Slides were examined using a Leica DMLB microscope (Leica Microsystems, Wetzlar, Germany) and imaged using a QICAM (QImagine, Surrey, BC, Canada) digital camera. A total of 5 images were taken at $20 \times$ magnification for each well, and the percentage of cells staining positively for pHH3 was calculated for each image. To do so, nuclei positively stained for pHH3 were counted manually using the multi-point tool in ImageJ, and nuclei stained with DAPI were calculated using the ImageJ plugin nucleus counter to 
acquire the total number of cells (ImageJ, 2017). The average percentage of the 5 images was then calculated.

\section{TGF $\beta$ Receptor Type I Kinase Inhibition}

The activity of TGF $\beta$ receptor type I (T $\boldsymbol{\beta R I}$ ) kinase activity was inhibited with LY (Herbertz et al., 2015). The MAC-T and BME-UV1 cells were seeded at densities of 1,000,000 and 4,000,000 cells, respectively, in 100-mm plates, each treated with TGF $\beta 1-/ L Y-$ dimethyl sulfoxide (DMSO) alone control], TGF $\beta 1+/$ $\mathrm{LY}-(\mathrm{TGF} \beta 1$ at $5 \mathrm{ng} / \mathrm{mL}), \mathrm{TGF} \beta 1+/ \mathrm{LY}+(\mathrm{TGF} \beta 1$ at $5 \mathrm{ng} / \mathrm{mL}$ plus LY at $5 \mu M$ ), or TGF $\beta 1-/ \mathrm{LY}+$ (LY at $5 \mu M)$. Cells were allowed to grow for $1 \mathrm{~d}$ before being starved in basal medium containing $0.2 \%$ FBS for $16 \mathrm{~h}$. Following starvation, cells were pretreated with $5 \mu M$ $\mathrm{LY}$ for $2 \mathrm{~h}$ in the TGF $\beta 1+/ \mathrm{LY}+$ and TGF $\beta 1-/ \mathrm{LY}+$ plates. The TGF $\beta 1-/ L Y-$ and TGF $\beta 1+/ L Y-$ plates were pretreated for $2 \mathrm{~h}$ with an equivalent volume of DMSO (the vehicle for LY; Fisher Scientific). After pretreatment with LY or DMSO, cells were treated with or without $5 \mathrm{ng} / \mathrm{mL}$ TGF $\beta 1$. After $48 \mathrm{~h}$, cells were lysed as described in the Protein Preparation and Quantification section.

\section{AKT Inhibition}

To inhibit AKT activity, we used the pan-AKT inhibitor MK-2206 (Prêtre and Wicki, 2018). The MAC-T and BME-UV1 cells were seeded at densities of 1,000,000 and 4,000,000 cells, respectively, in 100 $\mathrm{mm}$ plates, each containing TGF $\beta 1-/ \mathrm{MK}-$ (DMSO alone control), TGF $\beta 1+/ \mathrm{MK}-(\mathrm{TGF} \beta 1$ at $5 \mathrm{ng} / \mathrm{mL})$, $\mathrm{TGF} \beta 1+/ \mathrm{MK}+(\mathrm{TGF} \beta 1$ at $5 \mathrm{ng} / \mathrm{mL}$ plus MK at 0.625 $\mu M)$, or TGF $\beta 1-/ \mathrm{MK}+(\mathrm{MK}$ at $0.625 \mu M)$. Cells were allowed to grow for $1 \mathrm{~d}$ before being starved in basal medium plus $0.2 \%$ FBS for $16 \mathrm{~h}$. Following starvation, cells were pretreated with $0.625 \mu M$ MK for $2 \mathrm{~h}$ in the TGF $31-/ \mathrm{MK}+$ and TGF $\beta 1+/ \mathrm{MK}+$ plates. The TGF $\beta 1-/ M K-$ and TGF $\beta 1+/ M K$ - plates were pretreated for $2 \mathrm{~h}$ with starvation medium supplemented with DMSO (the vehicle for MK; Fisher Scientific) at the same volume used to treat cells with MK. After $2 \mathrm{~h}$ of pretreatment with MK or DMSO, cells were treated with $5 \mathrm{ng} / \mathrm{mL}$ of TGF $\beta 1$. After $48 \mathrm{~h}$, cells were lysed as described in Protein Preparation and Quantification, above.

\section{Statistical Analysis}

Statistical analysis was performed using GraphPad PRISM 6.0 (GraphPad Software, San Diego, CA). Assumption of normality was adequately met for each data set, based on Anderson-Darling, Shapiro-Wilk,
Kolmogorov-Smirnoff, and Cramer-von Mises tests, performed with SAS version 9.4 (Cary, NC). Unpaired $t$-tests were used for all experiments including 2 treatments (control and TGF $\beta 1$ ) evaluated at $48 \mathrm{~h}$. For the TGF $\beta 1$ time course and the AKT inhibitor and T $\beta R I$ kinase inhibitor experiments, 1-way ANOVA was first used to analyze data. A post hoc Tukey's test was then used to determine significant differences between means. For cell cycle analysis and annexin V/PI experiments, 2-way ANOVA was used to analyze data. Significant differences between means were subsequently determined using post hoc Bonferroni multiple comparisons tests. Differences between means were considered statistically significant when the $P$-value was $<0.05$. Error was represented by standard error of the mean.

\section{RESULTS AND DISCUSSION}

\section{Effect of TGF $\beta 1$ on PCD and Its Mediators}

Programmed Cell Death. As a first step to address the mechanistic aspects of PCD induced by TGF $\beta 1$ in BME-UV1 and MAC-T, we first examined the effect of TGF $\beta 1$ on PCD. Cleavage of caspase 3 is reportedly involved in TGF $\beta 1$-induced PCD of primary bovine mammary epithelial cells and in BME-UV1 cells (Kolek et al., 2003; Di et al., 2012). Therefore, we chose CC3 as a marker to evaluate TGF 31 -induced $\mathrm{PCD}$ via immunoblotting (Figure 1A). In MAC-T cells, CC3 was reduced $(P=0.014)$ in response to TGF $\beta 1$ at $48 \mathrm{~h}$ compared with control cells (Figure 1A, B). In BME-UV1 cells, CC3 was increased $(P=0.005$; Figure $1 \mathrm{~A}, \mathrm{~B})$ in response to TGF $\beta 1$ at $48 \mathrm{~h}$ compared with control cells. Kolek et al. (2003) reported that TGF $\beta 1$ induced PCD in BME-UV1. Our results reproduced these findings in BME-UV1, but not in MAC-T cells. This different behavior of MAC-T and BME-UV1 cells may be a function of their different phenotypes, as reported by Zarzyńska et al. (2005) and later confirmed by Arévalo Turrubiarte et al. (2016) and other groups (reviewed in Mitz and Viloria-Petit, 2019). Indeed, MAC- $\mathrm{T}$ cells have been reported to encompass a heterogeneous population that includes luminal or ductal-like and myoepithelial-like cell types, and to generate both luminal and myoepithelial cells when transplanted into murine mammary fat pads. In contrast, BME-UV1 cells have been reported to express luminal markers in addition to CD10 (Maspin) and aldehyde dehydrogenase, suggesting an enrichment of luminal progenitor cells in BME-UV1 cells (reviewed in Mitz and Viloria-Petit, 2019).

To verify that CC3 was reflecting the effects of TGF 31 on cell survival in BME-UV1 and MAC-T cells, we performed an annexin V/PI assay to independently 
detect PCD using flow cytometry (Supplemental Figure S1; https://doi.org/10.3168/jds.2019-17460). In MAC$\mathrm{T}$ cells, we found no statistically significant change in early PCD $(P=0.140$; annexin $\mathrm{V}+/ \mathrm{PI}-)$ or in late cell death $(P>0.999$; annexin $\mathrm{V}+/ \mathrm{PI}+$; Supplemental Figure S1A and B) at $48 \mathrm{~h}$. In BME-UV1 cells, we found no statistically significant change in early $\mathrm{PCD}(P=$ 0.096; annexin $\mathrm{V}+/ \mathrm{PI}-)$; however, late cell death was significantly greater $(P=0.026$; annexin $\mathrm{V}+/ \mathrm{PI}+)$ in the TGF $\beta 1$-treated group than in the control group at $48 \mathrm{~h}$ (Supplemental Figure S1A and C). Together with the CC3 results, these findings allowed us to conclude that BME-UV1 cells were dying in response to TGF $\beta 1$ at $48 \mathrm{~h}$, but MAC-T cells were not.

The different effects of TGF $\beta 1$ on MAC-T (myoepithelial- and ductal-like profile) and BME-UV1 (luminal-like profile; Arévalo Turrubiarte et al., 2016) may reflect what occurs in different subsets of mammary epithelial cells during bovine involution. For example, bovine mammary glands typically undergo regenerative involution, which involves overall turnover of luminal

\section{A}

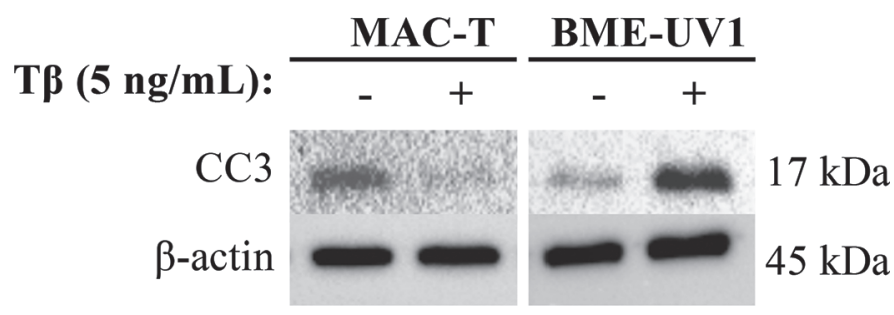

B

\section{$\mathrm{CC3}$}

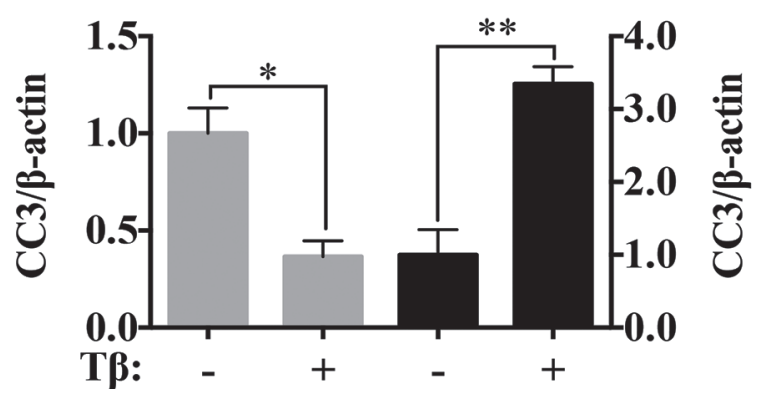

Figure 1. Changes in cleaved caspase 3 (CC3) protein expression after $48 \mathrm{~h}$ of transforming growth factor $\beta 1(\mathrm{~T} \beta)$ treatment in MAC-T and BME-UV1 cells. (A) Representative Western blots for MAC-T and BME-UV1 cell lines; (B) levels of CC3 relative to $\beta$-actin in MAC-T (gray bars) and BME-UV1 (black bars). Values shown are mean \pm SEM. At least 3 independent replicates were performed for each treatment. Statistical significance $\left({ }^{*} P<0.05 ;{ }^{*} P<0.01\right)$ was determined using unpaired $t$-tests. alveolar (secretory) epithelial cells without significant tissue remodeling, similar to mice with a concurrent pregnancy (Pai and Horseman, 2011). However, even in the greatly remodeled glands of nonpregnant mice, myoepithelial cells were shown to survive and to remain organized during the whole process of involution (Pai and Horseman, 2011). Thus, our findings might reflect the possibility that TGF $\beta 1$ induces PCD in the bovine mammary gland selectively by targeting luminal alveolar cells, but not myoepithelial or ductal cells.

TGFß1 Modulation of FOXO1. Several AKT targets are involved in cell cycle regulation and PCD. These include glycogen synthase kinase $\beta$ (Cross et al., 1995); the cell cycle inhibitors p21, p27, and p53 (Franke et al., 2008); the mammalian target of rapamycin complex 1 (mTORC1; Chen et al., 2010); the BH3-only protein BAD (del Peso et al., 1997); and the FOXO transcription factors (Huang and Tindall, 2007). In bovine epithelial cells, TGF $\beta 1$ reduces PI3K/AKT activity, which translates into increased $\mathrm{BAD}$ expression and PCD (Gajewska and Motyl, 2004; Di et al., 2012); however, involvement of the FOXO transcription factors in TGF $\beta 1$-induced PCD of bovine mammary cells has not been reported. Based on this and extensive testing of FOXO antibodies for reliable bovine reactivity, we decided to characterize FOXO1 expression in response to $48 \mathrm{~h}$ TGF $\beta 1$ treatment via immunoblotting. We did not observe a significant change $(P=$ 0.91) in FOXO1 expression in MAC-T cells, but we did observe significantly increased $(P=0.003)$ expression of FOXO1 in BME-UV1 cells (Figure 2A, B). This finding was correlated with the apoptotic response we observed at $48 \mathrm{~h}$ in BME-UV1 cells, and suggested a potential involvement of FOXO1 transcription factors in TGF 31 -induced PCD. In support of this possibility, FOXO1 was recently shown to be a key mediator of PCD of mammary epithelial cells during the pubertal stage of the mouse mammary gland (Sreekumar et al., 2017)

TGF $\beta 1$ Modulation of BIM. We know that BIM is a $\mathrm{BH} 3$-only protein involved in the intrinsic apoptotic cascade and a mediator of TGF $\beta 1$-induced cell death (Ramesh et al., 2009). It has 3 isoforms: BIM EL (extra-long), BIM L (long), and BIM S (short). The longest and most abundant isoform is BIM EL, and the shortest, least abundant, and most potent in inducing PCD is BIM S (Bouillet et al., 2001). In addition, FOXO1 acetylation results in BIM activation, and BIM is a target of the PI3K/AKT-FOXO1 signaling axis (Yang et al., 2009). In BME-UV1 cells, BIM L and BIM $\mathrm{S}$ expression were significantly increased $(P=0.006$ and $P=0.009$, respectively) in response to TGF $\beta 1$ treatment, but the levels of BIM EL were not significantly changed $(P=0.97$; Figure $2 \mathrm{~A}, \mathrm{C}, \mathrm{D}$, and $\mathrm{E})$. 
A
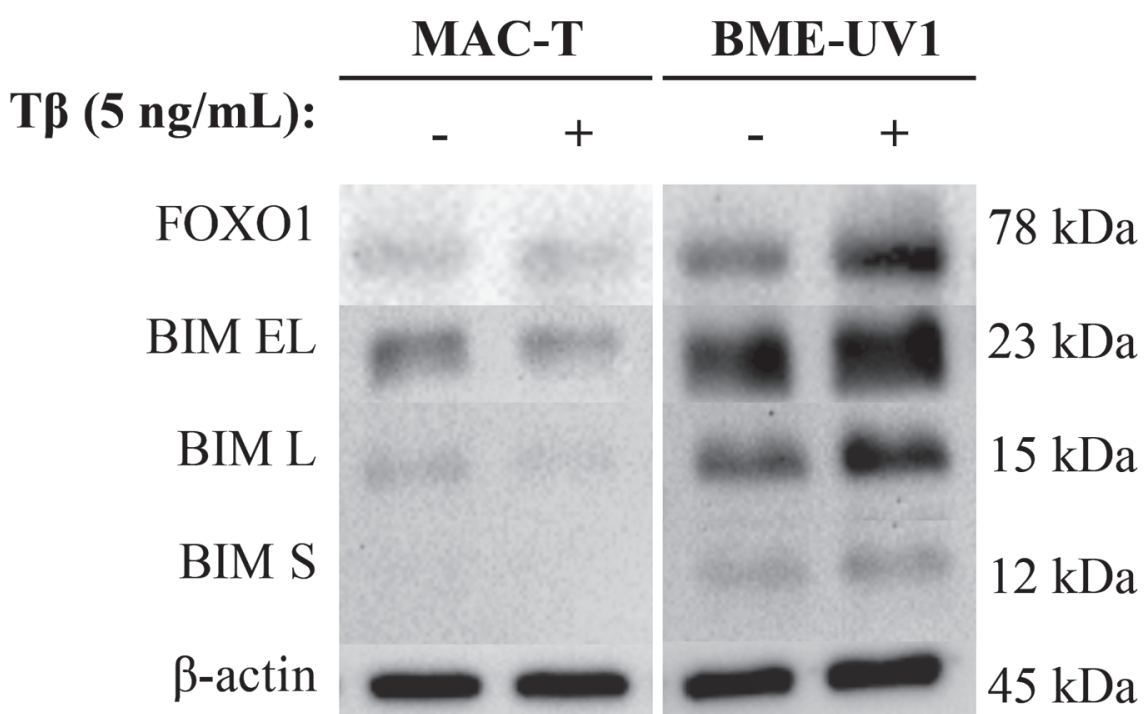

B

FOXO1

C
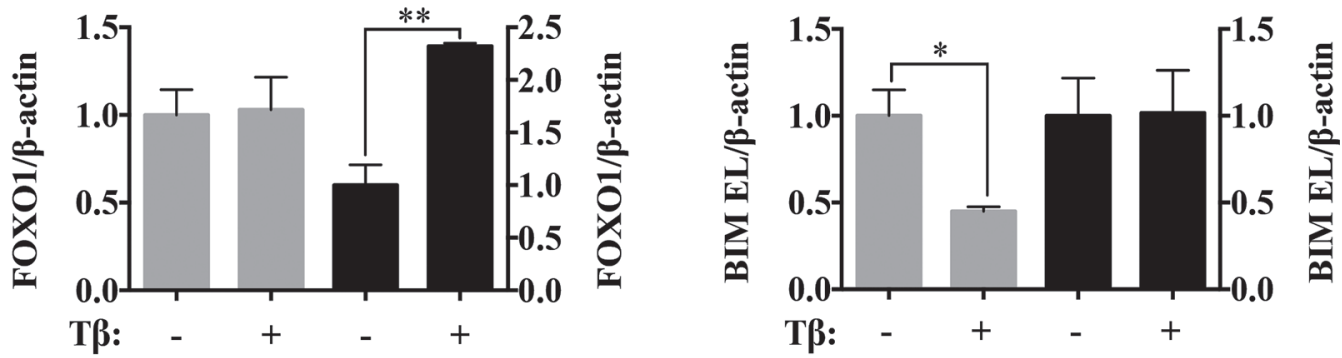

D

BIM L

E

\section{BIM S}
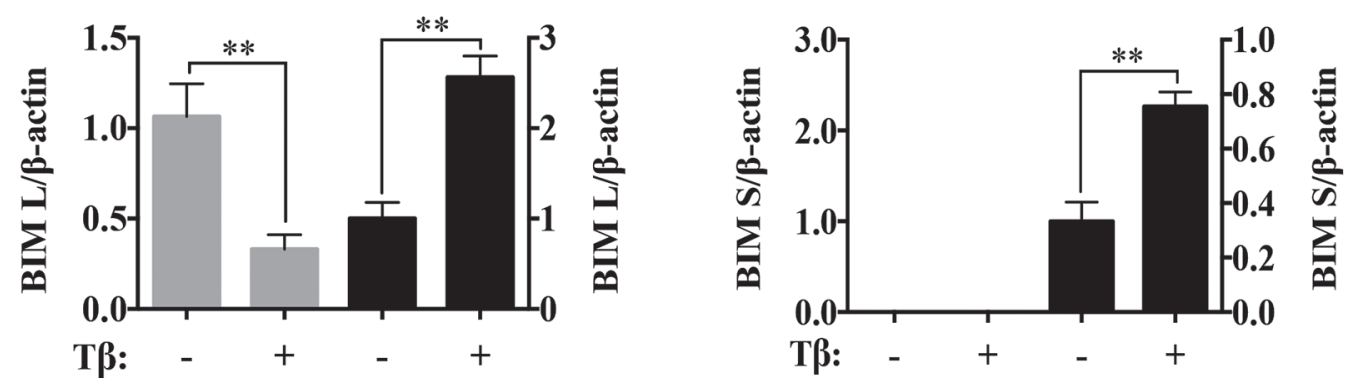

Figure 2. Changes in forkhead box transcription factors class O 1 (FOXO1), Bcl-2 interacting mediator of cell death (BIM) extra-long (EL), BIM long (L), and BIM short (S) protein expression after $48 \mathrm{~h}$ of transforming growth factor $\beta 1$ (T $\beta$ ) treatment in MAC-T and BME-UV1 cells. (A) Representative Western blots for MAC-T and BME-UV1 cell lines; and relative levels of (B) FOXO1, (C) BIM EL, (D) BIM L, and (E) BIM S in MAC-T (gray bars) and BME-UV1 (black bars) cell lines. Values shown are mean \pm SEM. At least 3 independent replicates were performed for each treatment. Statistical significance $\left({ }^{*} P<0.05 ;{ }^{* *} P<0.01\right)$ was determined using unpaired $t$-tests. 
Upregulation of BIM L and BIM S isoforms suggests the involvement of the intrinsic pathway of PCD in the TGF $\beta 1$ response of BME-UV1 cells. We found the opposite result in MAC-T cells, in which BIM expression was reduced by TGF $\beta 1$, consistent with the suppressive effects that TGF $\beta 1$ has on CC3 expression in these cells. In MAC-T cells, BIM EL and BIM L expression was significantly reduced $(P=0.022$ and $P=0.006$, respectively) at $48 \mathrm{~h}$ in response to TGF $\beta 1$ (Figure $2 \mathrm{~A}$, $\mathrm{C}$, and $\mathrm{D}$ ), and BIM $\mathrm{S}$ was not detected (Figure 2A, $\mathrm{E})$. This might have been due to the transient expression of BIM S during PCD (Lei and Davis, 2003); this isoform might be detected in MAC-T cells if alternate time points were evaluated.

\section{TGF $\beta 1$ Modulation of AKT and SMAD3}

Effect of TGF 1 on AKT and SMAD3 at 48 $h$. Both the canonical SMAD pathway and the PI3K/ AKT pathway mediate PCD in response to TGF $\beta 1$ in mammary epithelium. To verify canonical SMAD activation, we evaluated phosphorylation of SMAD3 by immunoblotting after $48 \mathrm{~h}$ of TGF $\beta 1$ treatment in MAC$\mathrm{T}$ and BME-UV1 cells (Figure 3 ). We chose the $48 \mathrm{~h}$ time point because we observed significant apoptotic effects mediated by TGF $\beta 1$ in BME-UV1 cells at this time (Figure 1). Therefore, we evaluated the expression of mediators of PCD and TGF $\beta 1$ signaling at $48 \mathrm{~h}$ in both MAC-T and BME-UV1 cells to keep time points consistent between cell lines and assays. We found that SMAD3 phosphorylation was increased after $48 \mathrm{~h}$ of TGF $\beta 1$ treatment in both the MAC-T and BME-UV1 cell lines $(P=0.0005$ and $P=0.0024$, respectively; Figure 3A, B). Total levels of SMAD3 were reduced in both MAC-T and BME-UV1 cells at $48 \mathrm{~h}$, but this finding was significant only for MAC-T cells $(P=0.001$ for MAC-T vs. $P=0.094$ for BME-UV1; Figure 3A, C). These results confirmed canonical TGF $\beta 1$ signaling activation in response to $48 \mathrm{~h}$ of TGF $\beta 1$ treatment in both cell lines.

We evaluated phosphorylation of AKT (Ser 473), an indicator of activation, in parallel with SMAD activation after $48 \mathrm{~h}$ of TGF $\beta 1$ treatment in MAC-T and BME-UV1 cells. In MAC-T cells, AKT phosphorylation was significantly reduced $(P=0.018)$, but total levels of AKT were unchanged $(P=0.54)$ in response to TGF $\beta 1$ treatment (Figure $3 \mathrm{~A}, \mathrm{D}$, and E). In BMEUV1 cells, AKT phosphorylation was significantly increased $(P=0.031)$ in response to TGF $\beta 1$ at $48 \mathrm{~h}$, but total levels of AKT were not significantly changed $(P=0.41$; Figure $3 \mathrm{~A}, \mathrm{D}$, and $\mathrm{E})$. These results provide evidence that TGF $\beta 1$ has different effects on PI3K/ AKT activity in MAC-T and BME-UV1 cells.
Effect of TGFß1 on AKT and SMAD3 Over a 48-h Time Course. To better visualize the dynamics of activation of SMAD3 and AKT in response to TGF $\beta 1$ treatment over time, we assessed phosphorylation and total levels of these proteins over a $48 \mathrm{~h}$ time course, including time points of $0,3,6,12,24$, and 48 $\mathrm{h}$ (Figure 4A to E). The change in the levels of phospho-SMAD3 $(P=0.11$ and $P=0.14$ in MAC-T and BME-UV1 cells, respectively) and SMAD3 $(P=0.60$ and 0.47 in MAC-T and BME-UV1 cells, respectively) was not significant over this time course (Figure 4A, B, and $\mathrm{C}$ ). Although the ANOVA for pSMAD3 was not statistically significant, we did observe a trend toward increased SMAD3 phosphorylation at $3 \mathrm{~h}$ compared with the control at $0 \mathrm{~h}$, and this was sustained over 48 $\mathrm{h}$ in both MAC-T and BME-UV1 cells.

For both MAC-T and BME-UV1 cells, the change in levels of pAKT was significant $(P<0.0001$ and $P=$ 0.0024 , respectively), but not significant for AKT $(P=$ 0.52 and $P=0.62$, respectively) over the $48 \mathrm{~h}$ course of TGF $\beta 1$ treatment. The PI3K/AKT activity in MAC-T cells was significantly reduced at 3,6 , and 12 to $48 \mathrm{~h}$ of TGF 31 treatment $(P=0.0026, P=0.0001$, and $P$ $<0.0001$, respectively), compared with the control at $0 \mathrm{~h}$ (Figure 4A, D). In the BME-UV1 cells, AKT phosphorylation was increased at $3 \mathrm{~h}$ of TGF $\beta 1$ treatment compared with $0 \mathrm{~h}(P=0.005$; Figure $4 \mathrm{~A}, \mathrm{D})$. At $12 \mathrm{~h}$ and $24 \mathrm{~h}$ of TGF $\beta 1$ treatment, pAKT was significantly reduced $(P=0.003$ and $P=0.0066$, respectively) compared with the $3 \mathrm{~h}$ time point (Figure $4 \mathrm{~A}, \mathrm{D}$ ), and we observed an increase at the $48 \mathrm{~h}$ time point compared with the previous 2 time points (12 and $24 \mathrm{~h}$ ) and the 0 $\mathrm{h}$ time point, but these differences were not significant. A reduction in pAKT in response to TGF $\beta 1$ treatment at the same time points assessed here $(3,6,12,24$, and $48 \mathrm{~h}$ ) was reported for BME-UV1 cells (Gajewska and Motyl, 2004), which is not in agreement with the time-dependent changes in AKT phosphorylation that we have reported here. Because culture and treatment conditions were comparable between the 2 studies and our results were reproducible in all biological replicates, the discrepancy may reflect the use of different reagent sources, such as different antibody manufacturers for pAKT. We used a monoclonal antibody from Cell Signaling, and Gajewska and Motyl (2004) used a pAKT antibody from Santa Cruz Biotechnology. Cell passage might also contribute to cell response differences.

Effect of T $\beta R I$ Kinase Inhibition on PCD. To evaluate whether TGF $\beta 1$ effects on the PCD marker CC3 were dependent on the activity of T $\beta R I$ (the kinase that directly activates the SMAD pathway), we used the TßRI kinase inhibitor LY (Herbertz et al., 2015) in both MAC-T and BME-UV1 cells. We as- 
A

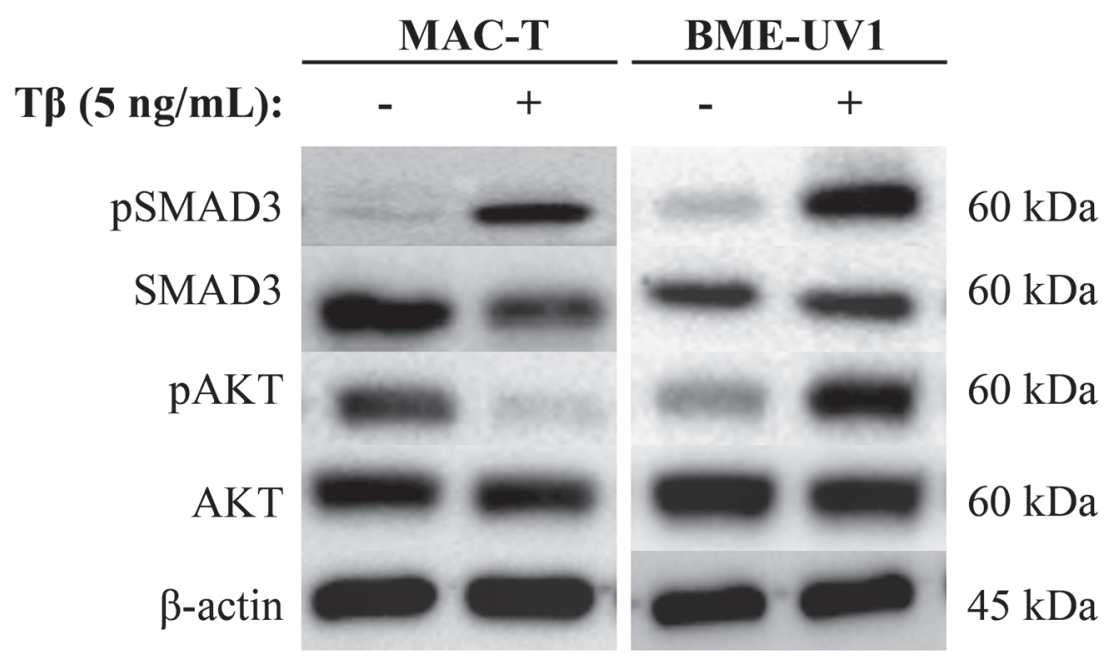

B

C

pSMAD3

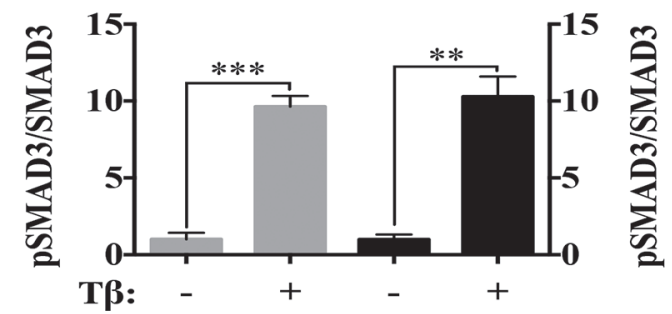

D

pAKT

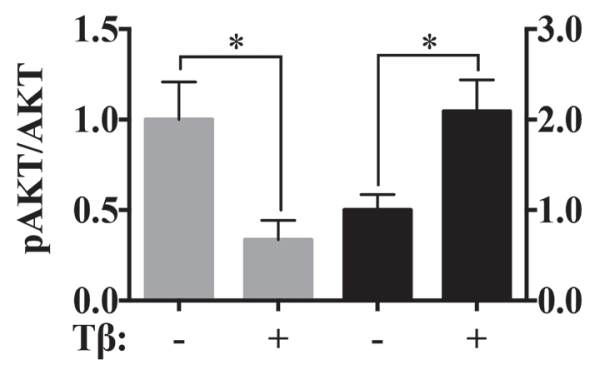

SMAD3

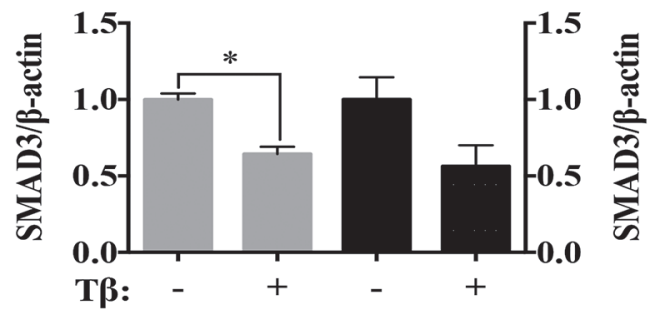

$\mathbf{E}$

AKT

Figure 3. Changes in phosphorylated (p)SMAD3/SMAD3 and pAKT/AKT after $48 \mathrm{~h}$ of transforming growth factor $\beta 1$ (T $\beta$ ) treatment in MAC-T and BME-UV1 cells. (A) Representative Western blots; and relative levels of (B) pSMAD3, (C) SMAD3, (D) pAKT, and (E) AKT in MAC-T (gray bars) and BME-UV1 (black bars) cell lines. Values shown are mean \pm SEM. At least 3 independent replicates were performed for each treatment. Statistical significance $\left({ }^{*} P<0.05 ;{ }^{* *} P<0.01 ;{ }^{* * *} P<0.001\right)$ was determined using unpaired $t$-tests.

sessed SMAD3 and AKT activation in parallel to CC3 expression to demonstrate blockade of T $\beta R I$ signaling and its effect on both PI3K/AKT signaling and PCD
(Figure 5). In MAC-T cells, phosphorylation of SMAD3 was significantly greater $(P<0.0001)$ in cells treated with TGF $\beta 1$ alone compared with all other treat- 
A

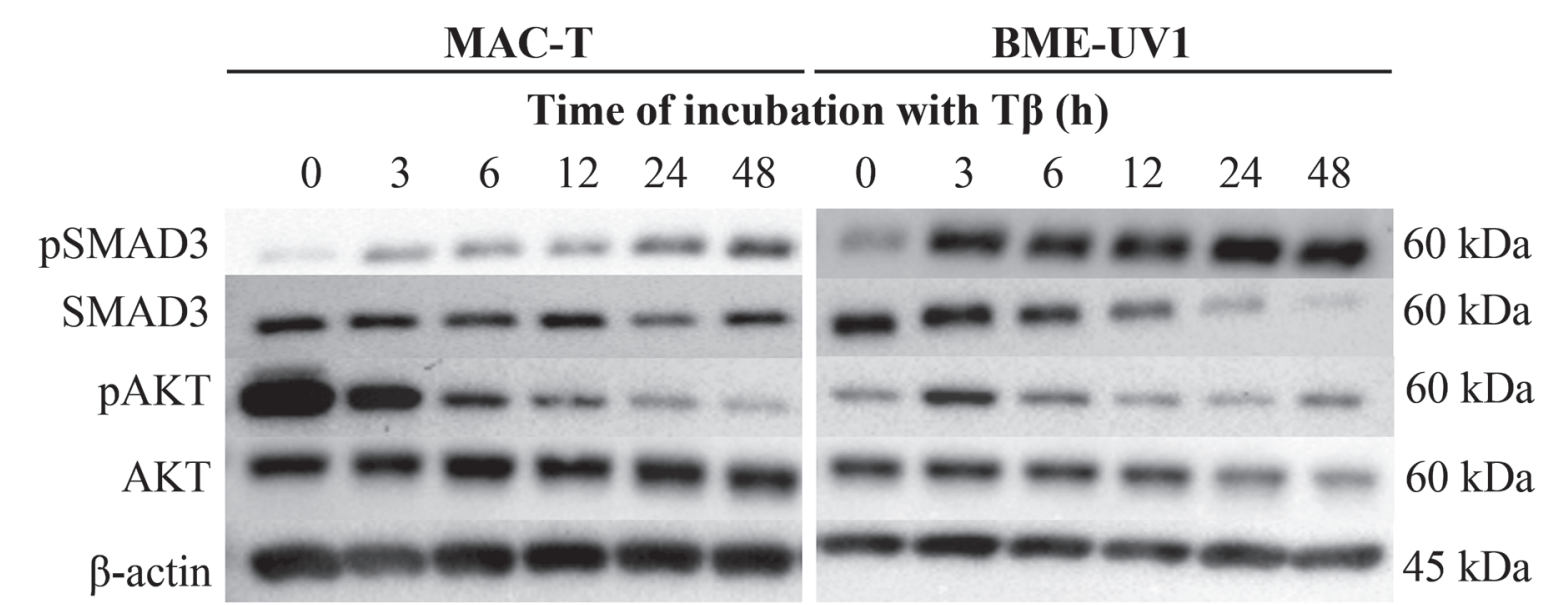

B

pSMAD3

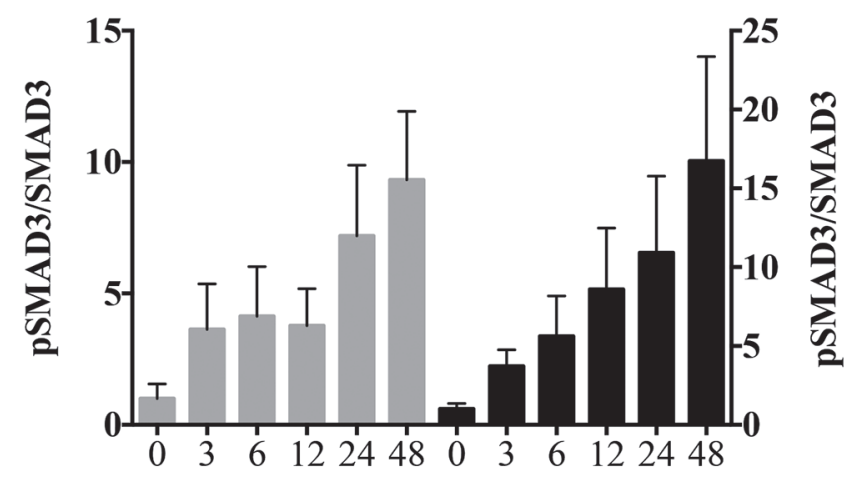

D

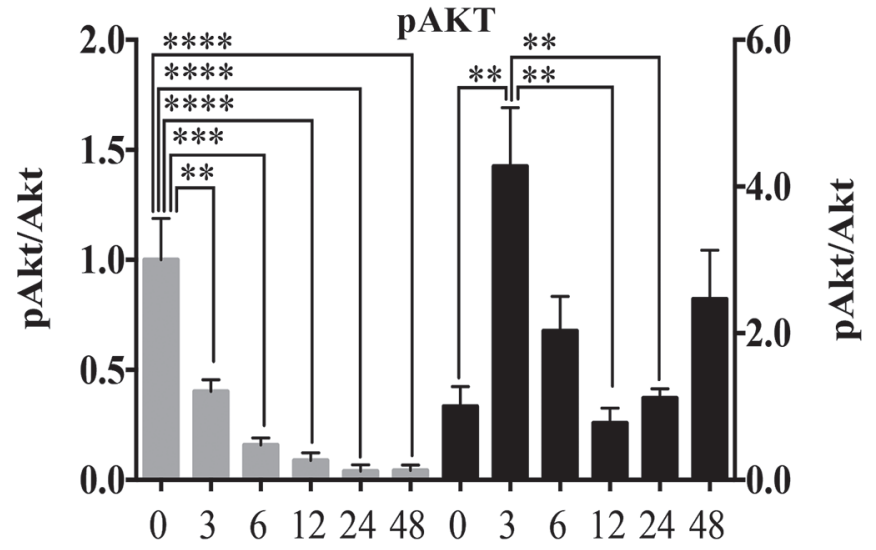

Time of incubation with $\mathrm{T} \beta$ (h)
C

\section{SMAD3}

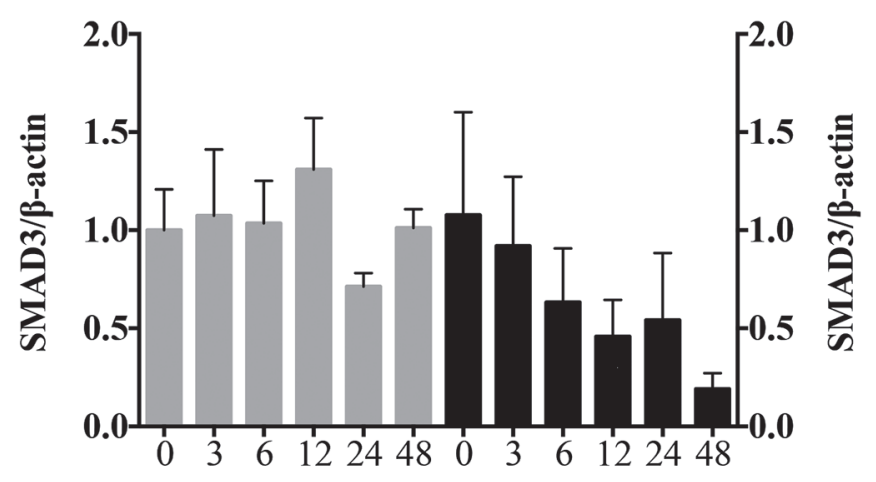

$\mathbf{E}$

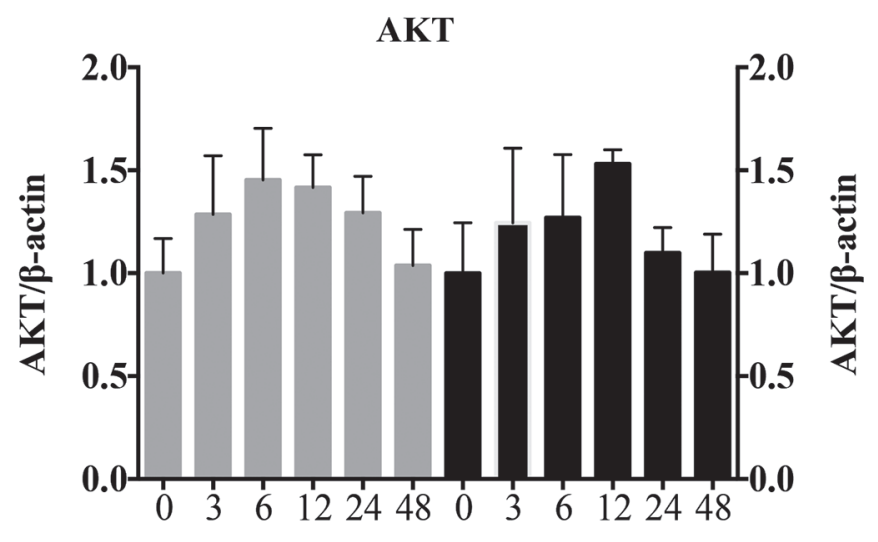

Time of incubation with $T \beta(h)$

Figure 4. Changes in phosphorylated (p)SMAD3/SMAD3 and pAKT/AKT protein expression after 0, 3, 6, 12, 24, and 48 h of transforming growth factor $\beta 1(\mathrm{~T} \beta)$ treatment in MAC-T and BME-UV1 cells. (A) Representative Western blots. Relative levels of (B) pSMAD3, (C) SMAD3, (D) pAKT, and (E) AKT in MAC-T (gray bars) and BME-UV1 (black bars) cell lines. Values shown are mean \pm SEM. At least 3 independent replicates were performed for each treatment. Statistical significance $\left({ }^{* *} P<0.01\right.$; $\left.* * * P<0.001 ; * * * * P<0.0001\right)$ was determined using 1-way ANOVA and post hoc Tukey tests. 
ments, and LY abrogated SMAD3 activation induced by TGF $\beta 1$ (Figure $5 \mathrm{~A}$ and $\mathrm{C}$ ). Inhibition of T $\beta \mathrm{RI}$ kinase activity did not reverse the suppressive effect of exogenous TGF 31 on CC3 expression, suggesting that TRRI/SMAD signaling does not promote this effect in MAC-T cells (Figure 5A, B). In fact, we observed an unexpected increase in $\mathrm{CC} 3$ expression $(P=0.032)$ in the LY+/T $\beta$ - group (treated with LY alone) compared with the $\mathrm{LY}+/ \mathrm{T} \beta+$ group (treated with $\mathrm{LY}$ and TGF31). As observed before, TGFß1 inhibited AKT activation in MAC-T cells, and LY in combination with TGF $\beta 1$ rescued this effect of TGF $\beta 1$ on AKT activation (Figure 5A, $\mathrm{E} ; P=0.029$ ). This finding suggests that T $\beta R I$ signaling mediates PI3K/AKT inhibition in MAC-T cells, in agreement with previous reports implicating T $\beta R I$ kinase in PI3K modulation in mouse mammary epithelial cells (Yi et al., 2005).

In BME-UV1 cells, phosphorylation of SMAD3 was significantly greater $(P=0.0042, P=0.0015$, and $P=$ 0.0014) in cells treated with TGF $\beta 1$ alone compared with untreated cells, cells treated with LY alone, and cells treated with TGF $\beta 1+$ LY, respectively (Figure $5 \mathrm{~A}, \mathrm{C})$. This finding verifies the inhibitory effect of LY on canonical T $\beta R I / S M A D$ signaling. We found that CC3 expression was significantly enhanced $(P=0.011)$ by TGF $\beta 1$ treatment, and both basal and TGF 31 induced CC3 expression were completely abrogated $(P=0.0005)$ by LY treatment (Figure 5A, B). This finding demonstrates that TGF $\beta 1$-induced PCD in BME-UV1 cells is dependent on T $\beta R I$ kinase activity and may be mediated by its immediate downstream effector, SMAD3. The lack of effect of LY on AKT activation (Figure 5E) both in the presence and absence of TGF $\beta 1$ suggests that, contrary to what we found for MAC-T, TGF $\beta 1$ does not modulate PI3K/ AKT signaling via the T $\beta$ RI kinase in BME-UV1 cells. This finding highlights yet another difference between the 2 cell lines.

Effect of AKT Inhibition on PCD. The results described above showed that the levels of the PCD marker CC3 correlate positively with AKT activation following $48 \mathrm{~h}$ of TGF $\beta 1$ treatment in MAC-T and BME-UV1, suggesting that a sustained reduction in AKT activity is not a mediator of TGF $\beta 1$-induced PCD in either cell line. To better understand the role of AKT in TGFß1-induced PCD, we next treated the cells with TGF $\beta 1$ in the presence and absence of the AKT signaling inhibitor MK (Figure 6A to F), which inhibits activation of all 3 AKT isoforms (Prêtre and Wicki, 2018). In BME-UV1 and MAC-T cells, MK treatment significantly blocked activation of AKT in the absence and presence of TGF 31 (Figure 6A, C, $P$ $=0.015$ compared to TGF $\beta 1$ alone in BME-UV1, and $P=0.00040$ compared to untreated cells for MAC-T cells), but it did not affect the total levels of AKT in either cell line (Figure 6A, D). Treatment with TGF $\beta 1$ enhanced SMAD3 phosphorylation compared with untreated cells in the absence of MK (Figure 6A, E, $P=$ 0.029 for BME-UV1 and $P<0.0001$ for MAC-T) and in the presence of $\mathrm{MK}$ (Figure 6A, E, $P=0.023$ for BME-UV1 and $P<0.0001$ for MAC-T). Treatment with MK did not alter the levels of SMAD3 activation in the absence or presence of TGF $\beta 1$ in either cell line. Taken together, these results indicate activation of canonical signaling by TGF $\beta 1$, and MK specificity in inhibiting AKT but not SMAD signaling.

In BME-UV1 cells, phosphorylation of AKT increased in response to TGF $\beta 1$ compared with the control at $48 \mathrm{~h}$ (Figure 6C), in agreement with our initial observations (Figure 3A, D). This was an unexpected result of this study, because activation of AKT has been documented to promote cell survival or inhibit PCD (Gajewska and Motyl, 2004; Zarzyńska and Motyl, 2005), and therefore did not correlate with the significantly enhanced CC3 expression $(P=0.019)$ we also observed in BME-UV1 cells treated with TGF $\beta 1$ compared to untreated cells (Figure 6A, B). As well, CC3 was significantly increased $(P=0.0012$ and $P=$ 0.0042 ) in BME-UV1 cells treated with TGF $\beta 1$ plus MK compared with untreated cells and cells treated with MK alone, respectively. Although not statistically significant $(P=0.70$ and $P=0.18$, respectively), we observed trends toward enhanced expression of CC3 in cells treated with MK alone versus untreated cells, and in cells treated with TGF $\beta 1$ plus MK versus cells treated with TGF $\beta 1$ alone. This finding suggests that AKT inhibition enhances PCD of BME-UV1 cells, in agreement with the documented role of PI3K/AKT signaling in promoting cell survival in bovine mammary epithelial cells (Gajewska and Motyl, 2004; Zarzyńska and Motyl, 2005). Whether the transient yet prolonged reduction in AKT activity induced by TGF $\beta 1$ between 6 and $24 \mathrm{~h}$ in the $48 \mathrm{~h}$ time course (Figure 4A, D) played a role in TGF 31 -induced PCD in BME-UV1 cells remains to be determined.

In MAC-T cells, TGF $\beta 1$ treatment for $48 \mathrm{~h}$ reduces CC3 expression and AKT phosphorylation (Figure 6A, $\mathrm{B}$, and $\mathrm{C}, P=0.008$ for $\mathrm{pAKT}$ ). Treatment with MK in the presence of TGF $\beta 1$ does not alter CC3 levels compared to TGF $\beta 1$ alone, and CC3 levels were significantly reduced $(P=0.014)$ rather than increased by MK treatment alone compared to no treatment (Figure $6 \mathrm{~A}, \mathrm{~B})$. Based on this finding, we conclude that AKT signaling inhibition does not enhance PCD of MAC$\mathrm{T}$ cells, and these cells do not behave as expected for bovine mammary epithelial cells, in which PI3K/AKT mediates somatotropic signaling, promotes cell survival, and thus inhibits the pro-apoptotic function of TGF $\beta 1$ 
A

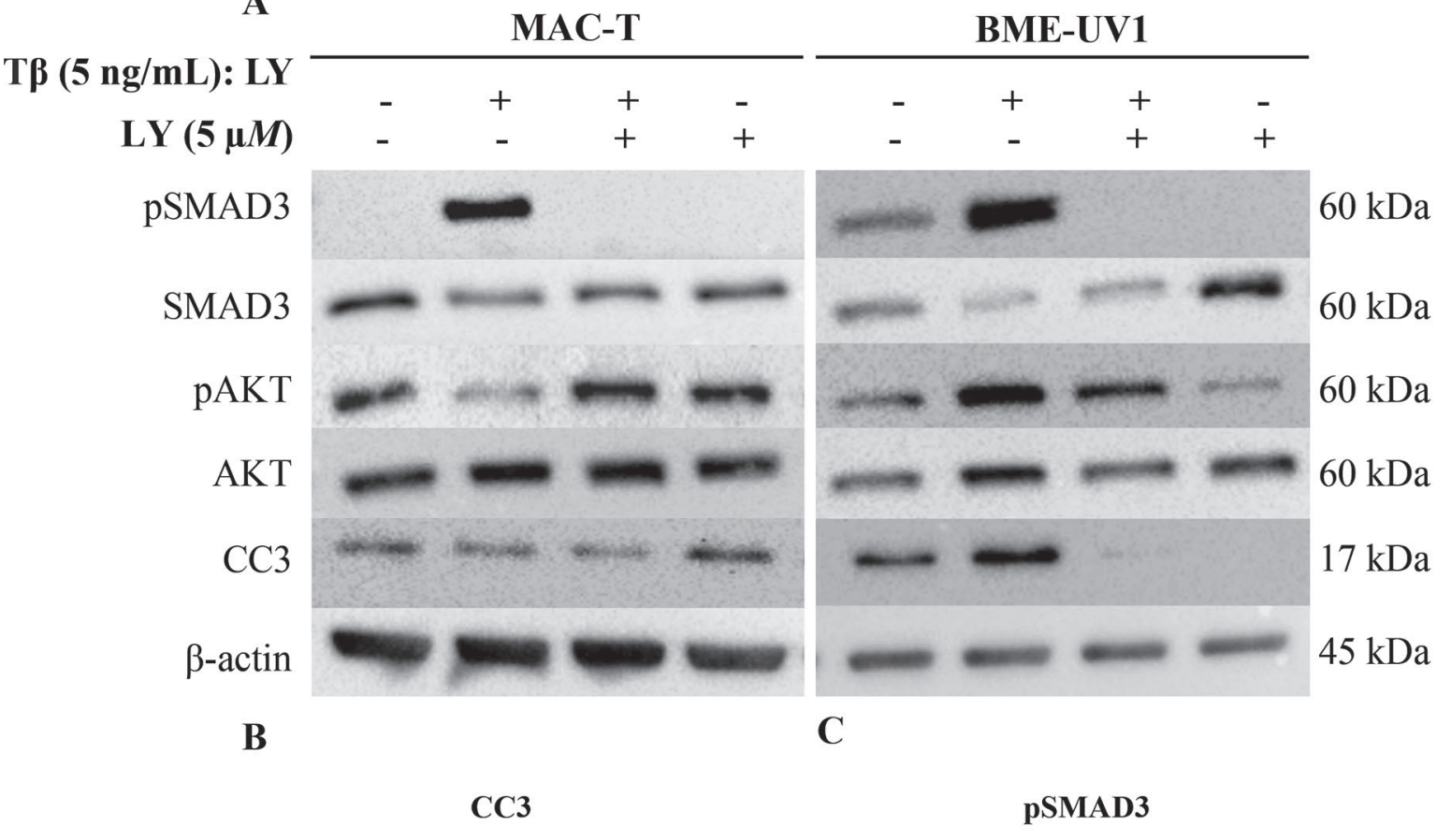

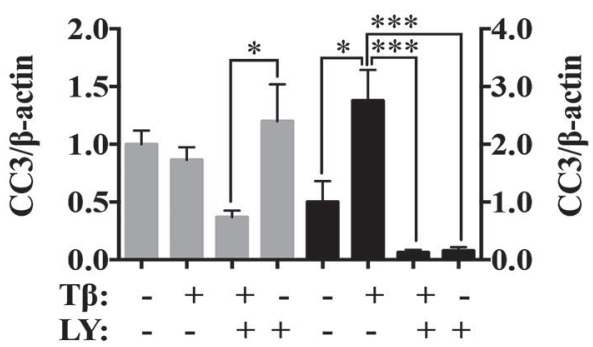

$\mathbf{E}$
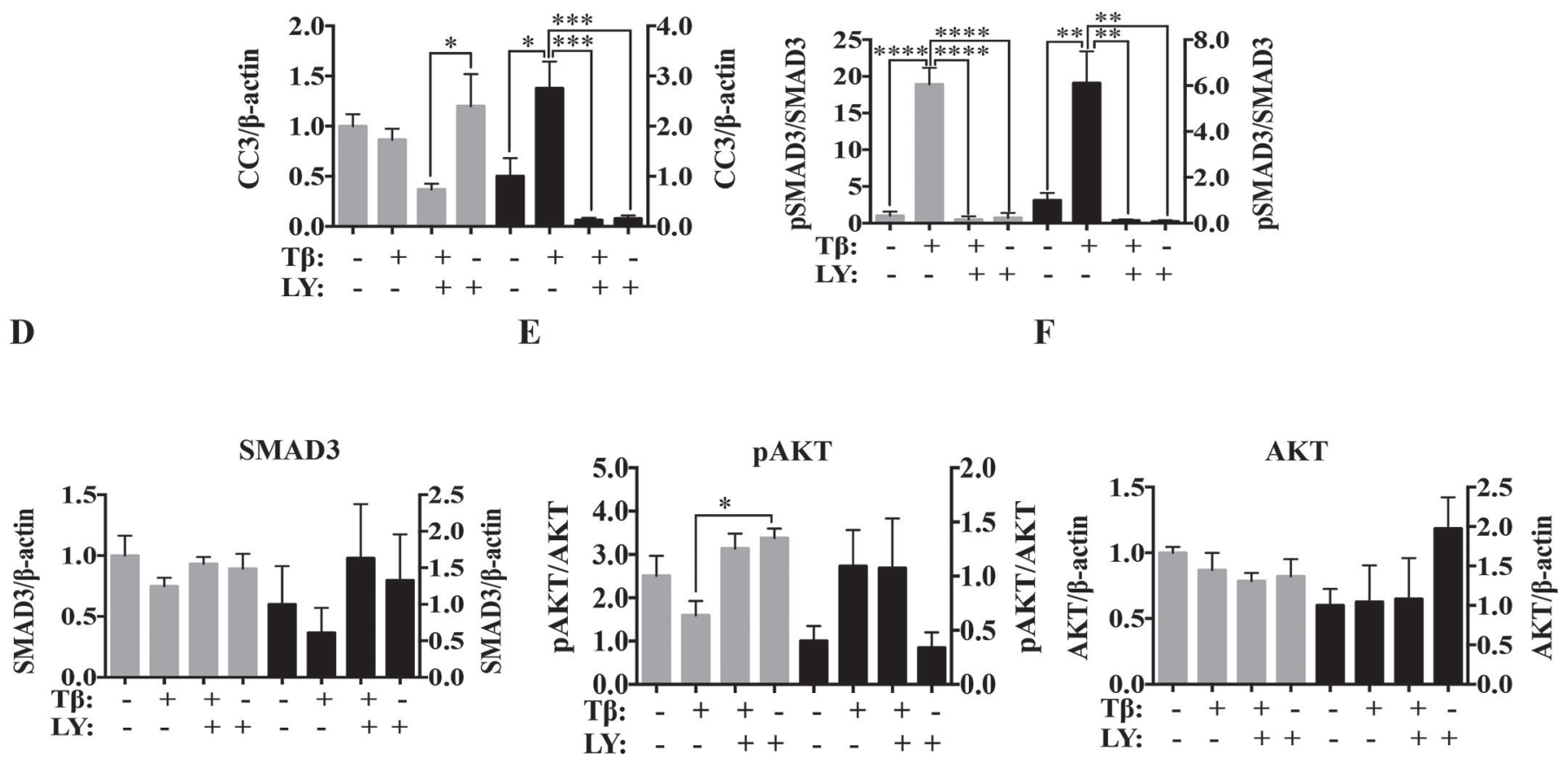

Figure 5. Effect of T $\beta R I$ kinase inhibition (LY) in MAC-T and BME-UV1 cells. (A) Western blot of BME-UV1 cells; and relative levels of (B) cleaved caspase 3 (CC3), (C) phosphorylated (p)SMAD3, (D) SMAD3, (E) pAKT, and (F) AKT in MAC-T (gray bars) and BME-UV1 (black bars) cell lines after $48 \mathrm{~h}$ of transforming growth factor $\beta 1$ (T $\beta$ ) treatment. Values shown are mean \pm SEM. At least 3 independent replicates were performed for each treatment. Statistical significance $\left({ }^{*} P<0.05 ; * * P<0.01 ; * * * P<0.001\right.$; $\left.{ }^{* * * *} P<0.0001\right)$ was determined using 1-way ANOVA and post hoc Tukey's tests.

(Gajewska and Motyl, 2004; Zarzyńska and Motyl, 2005 ). Whether the lack of activation or the overactivation of other pathways apart from PI3K/AKT is responsible for the inability of TGF $\beta 1$ to promote PCD in MAC-T cells remains to be determined. Of note, the signal transduction and activator of transcription 3 (STAT3), a transcription factor activated by the Janus kinase (JAK), was shown to be required for optimal 
A
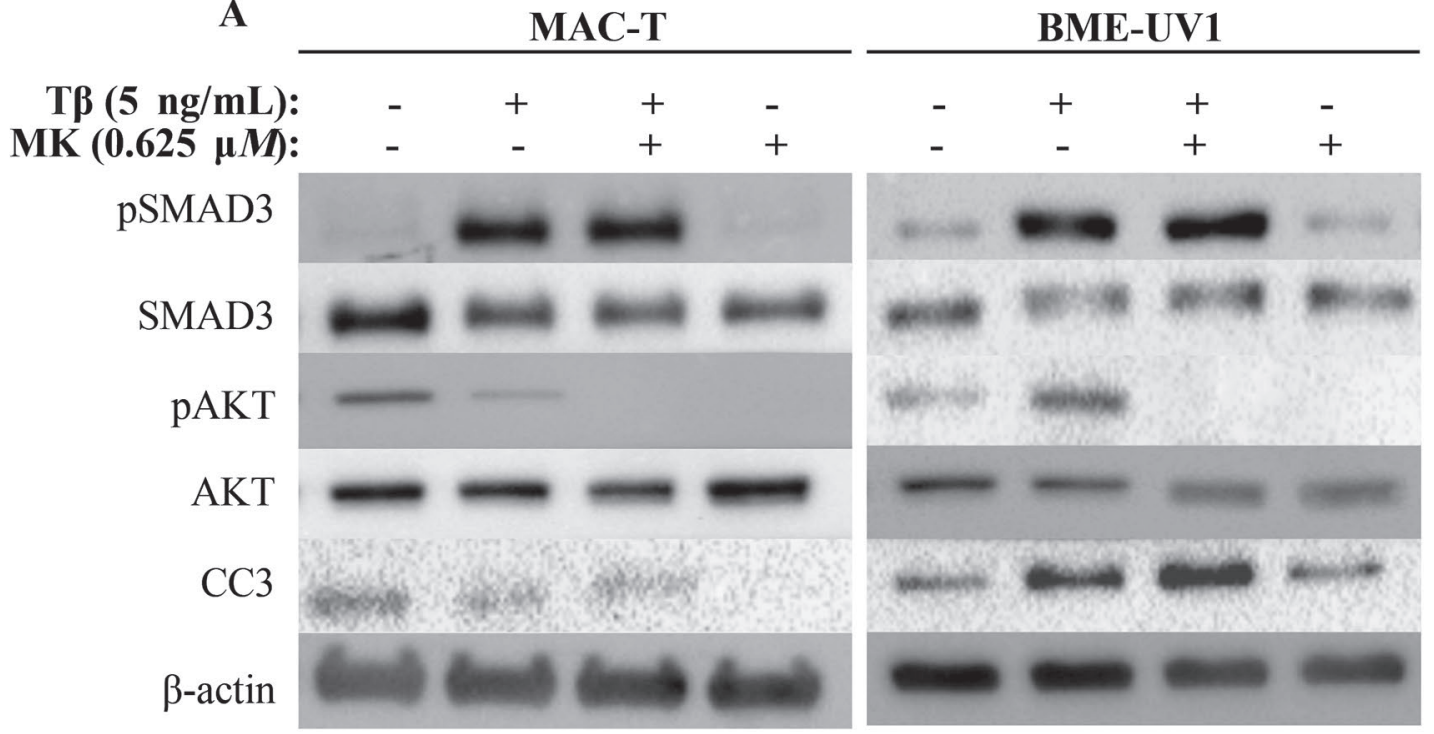

$60 \mathrm{kDa}$

$60 \mathrm{kDa}$

$60 \mathrm{kDa}$

$60 \mathrm{kDa}$

$17 \mathrm{kDa}$

$45 \mathrm{kDa}$

B

C

D

CC3

pAKT

AKT

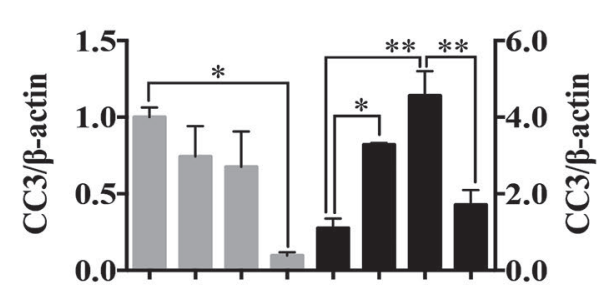

T及: - + + - ++

MK: - $-++-\quad++$
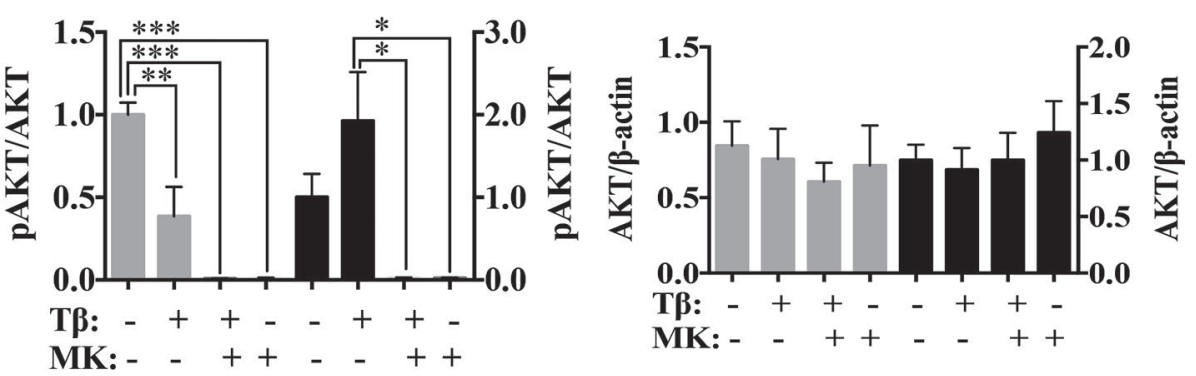

$\mathbf{E}$

F

pSMAD3

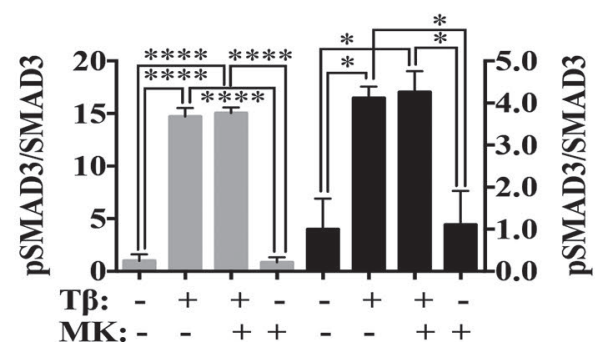

SMAD3

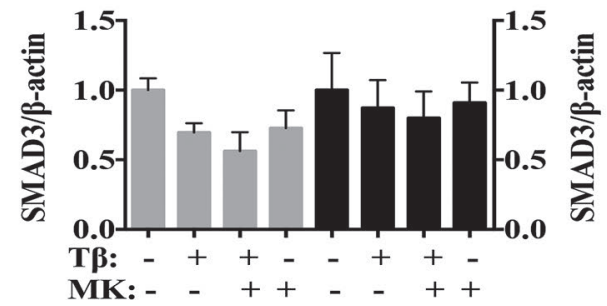

Figure 6. Effect of AKT inhibition (MK) in MAC-T and BME-UV1 cells. (A) Western blot of BME-UV1 cells; and relative levels of (B) cleaved caspase 3 (CC3), (C) phosphorylated (p)AKT, (D) AKT, (E) pSMAD3, and (F) SMAD3 in MAC-T (gray bars) and BME-UV1 (black bars) cell lines after $48 \mathrm{~h}$ of transforming growth factor $\beta 1(\mathrm{~T} \beta)$ treatment. Values shown are mean \pm SEM. At least 3 independent replicates were performed for each treatment. Statistical significance $\left({ }^{*} P<0.05\right.$; ${ }^{* *} P<0.01$; ${ }^{* * *} P<0.001$; $\left.{ }^{* * *} P<0.0001\right)$ was determined using 1 -way ANOVA and post hoc Tukey tests.

PCD during the first phase of mammary gland involution in mice (Chapman et al., 1999; Humphreys et al., 2002), and this is in agreement with an increase in STAT3 phosphorylation observed at the onset of involution in the bovine mammary gland (Singh et al., 2016). Interestingly, TGF $\beta$ was reported to activate 
STAT3 in epithelial cell lines (Tang et al., 2017), suggesting that differences in the activation of the JAK/ STAT3 pathway in BME-UV1 and MAC-T cells may explain, at least in part, their different PCD responses to TGF $\beta$.

\section{Effect of TGF $\beta 1$ on Growth Arrest}

Effect of TGFß1 on Cell Cycle. To evaluate the effect of TGF $\beta 1$ on cell cycling in the bovine mammary epithelium, we used the DNA-binding dye PI and analyzed this with flow cytometry to determine the percentage of cells in each of the major cell cycle phases $\left(G_{0} / G_{1}, S\right.$, and $G_{2} / M$; Figure $\left.7 A\right)$. Because we did not quantify cells in the sub- $\mathrm{G}_{1}$ region of the DNA histogram, the total percentage of cells did not amount to 100. As a general trend for both MAC-T and BMEUV1, TGF $\beta 1$ increased the percentage of cells in the $\mathrm{G}_{0} / \mathrm{G}_{1}$ phase and reduced the percentage of cells in the $\mathrm{S}$ or $\mathrm{G}_{2} / \mathrm{M}$ phases compared to untreated cells (Figure 7A, B, and $\mathrm{C}$ ), but this reached statistical significance only for the $\mathrm{G}_{0} / \mathrm{G}_{1}$ phase in MAC-T cells $(P=0.046)$. These results suggest that TGF $\beta 1$ induces $\mathrm{G}_{0} / \mathrm{G}_{1}$ cell cycle arrest in both BME-UV1 and MAC-T cells.

Effect of TGFß1 on Proliferation. Although PI staining provides an idea of the proportion of cells in each of the major cell cycle phases, it is not informative in terms of cell cycle kinetics or whether or not the treatment actually alters cell proliferation. Therefore, we assessed $\mathrm{pHH} 3$ expression in response to 48 $\mathrm{h}$ of TGFß1 treatment (Figure 8), because pHH3 is a marker of mitosis (Hans and Dimitrov, 2001). We found that TGF $\beta 1$ significantly reduced $(P=0.0058$ and $P$ $=0.00080$, respectively) the percentage of cells that stained positively for $\mathrm{pHH} 3$ in both MAC-T and BMEUV1 cells (Figure 8A, B, and C), indicating that both cell lines undergo growth arrest in response to TGF $\beta 1$. To determine if the antiproliferative effect of TGF $\beta 1$ is dependent on its capacity to downregulate PI3K/ AKT signaling, further experiments could assess the effect of AKT inhibition on cell proliferation, as well as the downstream targets of AKT involved in cellular proliferation and cell cycle progression, such as GSK-3 $\beta$ (Cross et al., 1995); the cell cycle inhibitors p21 and p27, as well as p53 (Franke et al., 2008), mTORC1 (Chen et al., 2010) and the FOXO transcription factors (Huang and Tindall, 2007).

\section{Summary}

The results presented here indicate that TGF $\beta 1$ has contrasting effects on PI3K/AKT modulation and PCD in MAC-T and BME-UV1 cells, as summarized in the model presented in Figure 9. Exogenous TGF $\beta 1$ promotes PCD in BME-UV1 cells but inhibits PCD (i.e., promotes survival) in MAC-T cells, and it inhibits growth in both cell lines. We found that T $\beta R I$ kinase activity is required for TGF $\beta 1$ to induce PCD in BMEUV1 cells but does not mediate the pro-survival effect of TGF $\beta 1$ in MAC-T cells. Further, T $\beta R I$ kinase modulates PI3K/AKT signaling in MAC-T but not in BME-UV1 cells. It was also evident that TGF 31 induced PCD is not necessarily mediated by a sustained reduction in AKT activation induced by this growth factor in either cell line, although AKT was shown to promote cell survival in BME-UV1 but not MAC-T cells. In agreement with this, the levels of 2 reported targets of AKT - namely FOXO1 and BIMwere significantly increased in parallel to PCD induction by TGF $\beta 1$ in BME-UV1 cells, but not in MAC-T cells. Taken together, these results indicate that the outcomes of TGF $\beta 1$ signaling activation in BME-UV1 and MAC-T cells are not equivalent, and suggest that for research on bovine mammary gland involution, the BME-UV1 cell line might be a more appropriate choice for addressing the effect of TGF $\beta$ in milk-producing luminal epithelial cells. This finding is in agreement with previously reported luminal lineage markers expressed by BME-UV1 cells. However, the contrasting effects of TGF $\beta 1$ on PCD in MAC-T and BME-UV1 cells should also be verified using the same culture conditions for both cell lines before TGF $\beta 1$ treatment, to ensure that medium composition-including differences in basal medium, growth factors, and hormones - was not responsible for cell phenotype.

\section{CONCLUSIONS}

In summary, TGF $\beta 1$ has contrasting effects on PCD in BME-UV1 versus MAC-T cells, whereby it promotes PCD in BME-UV1 but reduces PCD in MAC-T cells. The sustained reduction in PI3K/AKT activity caused by TGF $\beta 1$ in MAC-T cells does not induce PCD in this cell line. Additional studies are necessary to establish the specific role of PI3K/AKT and that of other potential and less explored pathways in bovine studies, in particular JAK/STAT3 signaling in cell survival/death in the BME-UV1 and MAC-T cell lines. Such studies will improve our understanding of the role of TGF $\beta$ in bovine mammary gland involution and guide future consideration of specific branches of TGF $\beta$ signaling as feasible targets for enhancing milk production.

\section{ACKNOWLEDGMENTS}

We thank members of the Viloria-Petit, Coomber, and Mutsaers labs (Department of Biomedical Sciences, University of Guelph, Ontario, Canada); Roger 
A

\section{MAC-T}
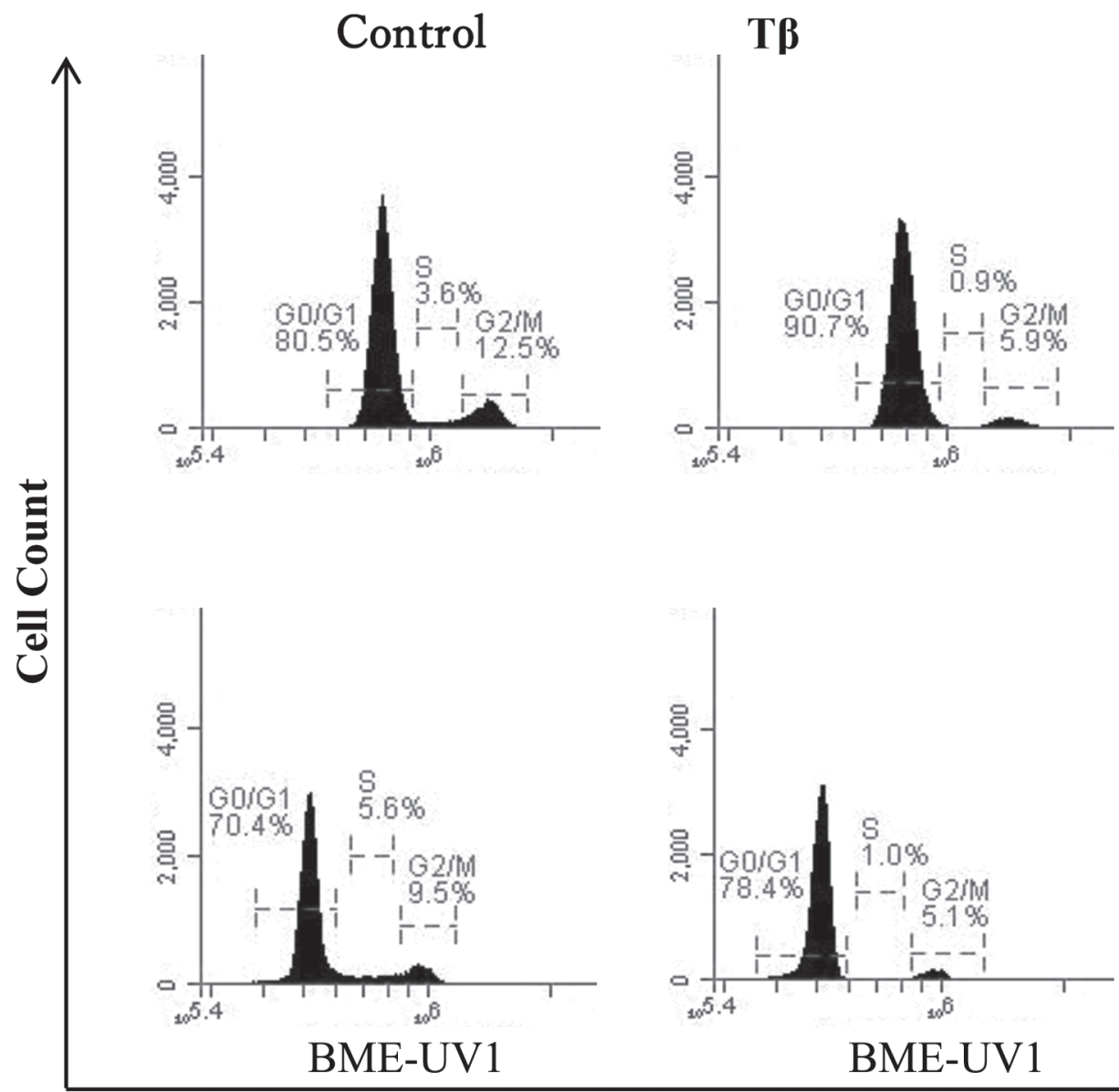

Propidium Iodide

B

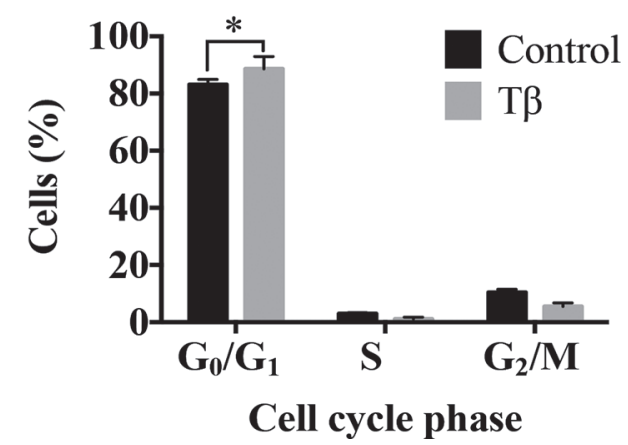

C BME-UV1

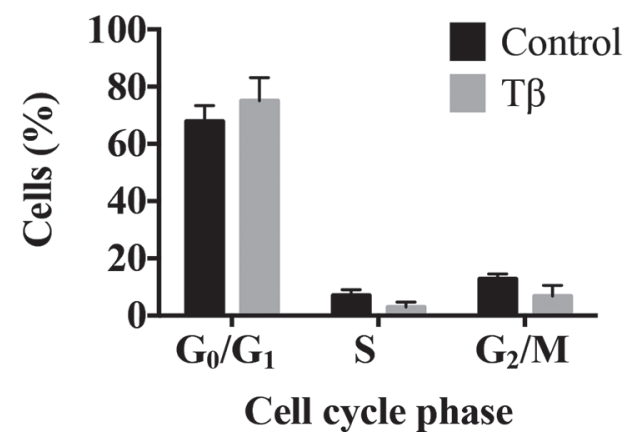

Figure 7. Effect of $48 \mathrm{~h}$ of transforming growth factor $\beta 1$ (TGF 31 ) treatment on cell cycle. (A) Representative flow cytometry plots for MAC-T cells and BME-UV1 cells treated with $5 \mathrm{ng} / \mathrm{mL}$ TGF $\beta 1$ for $48 \mathrm{~h}$. Cell cycle analysis after 48-h TGF 31 (T $\beta$ ) treatment in (B) MAC-T cells and (C) BME-UV1 cells. Values shown are mean \pm SEM. At least 3 independent replicates were performed for each treatment. Statistical significance $\left({ }^{*} P<0.05\right)$ was determined using 2 -way ANOVA and post hoc Bonferroni multiple comparison tests.

Moorehead and John P. Cant (Department of Biomedical Sciences and Department of Animal Biosciences, University of Guelph, ON, Canada); and statistical consultant William Sears (Ontario Veterinary College, University of Guelph, ON, Canada), for their input during the development of this research. We also thank 
A

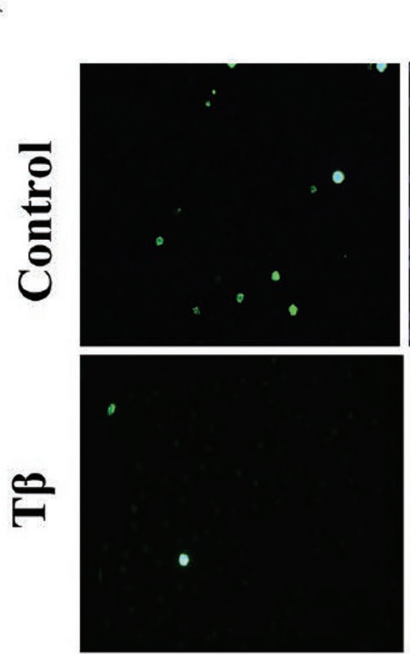

MAC-T
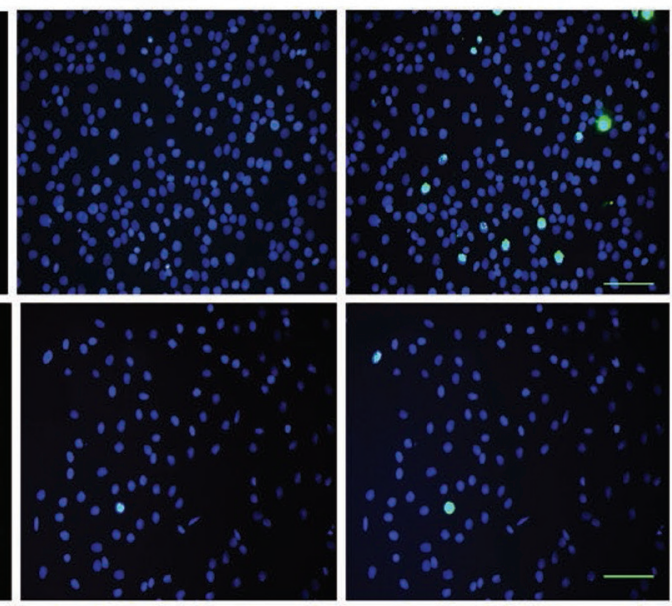

pHH3

Nuclei

Overlay

BME-UV1
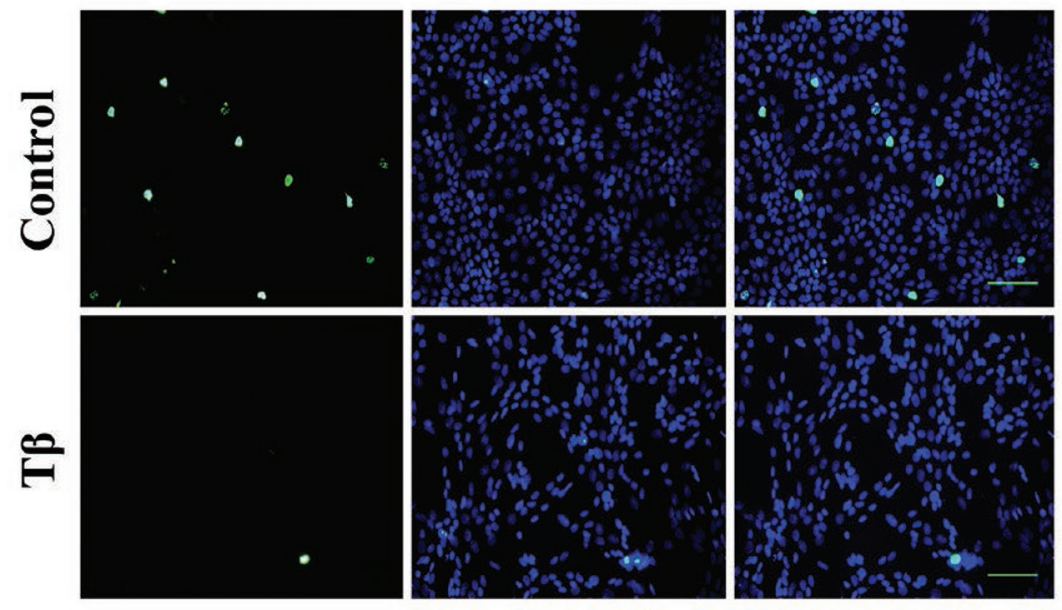

B

MAC-T

C

BME-UV1
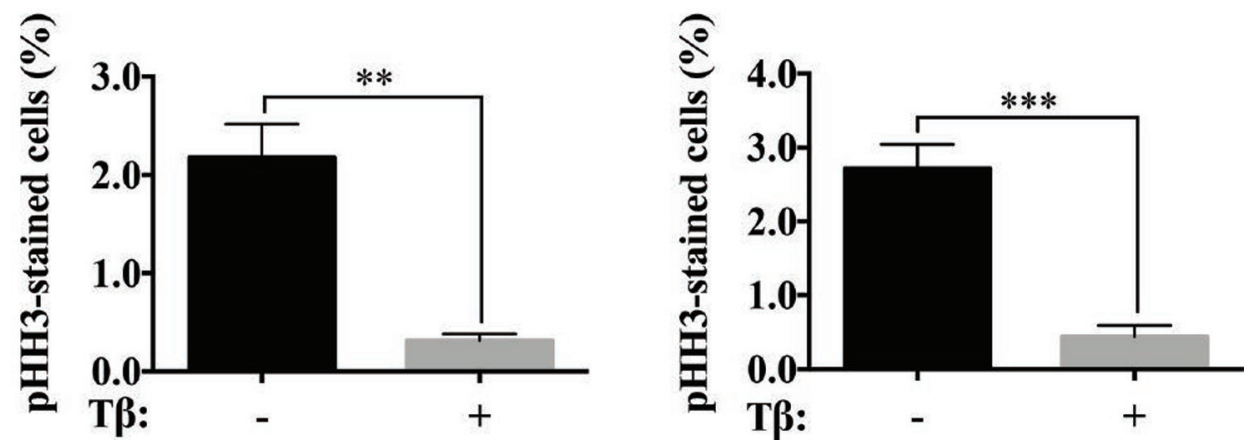

Figure 8. Effect of $48 \mathrm{~h}$ of transforming growth factor $\beta 1$ (T $\beta$ ) treatment on proliferation. (A) Images of MAC-T and BME-UV1 cells immunostained for phospho-histone $\mathrm{H} 3$ (pHH3; green) and nuclei labeled with 4',6-diamidino-2-phenylindole (DAPI; blue), following $48 \mathrm{~h}$ of treatment with $5 \mathrm{ng} / \mathrm{mL}$ of TGF31 or without (control). Scale bar $=50 \mu \mathrm{m}$. Quantification of pHH3 staining in (B) MAC-T and (C) BME-UV1 cell lines. Values shown are mean \pm SEM. At least 3 independent replicates were performed for each treatment group. Statistical significance $(* * P$ $\left.<0.01 ;{ }^{* * *} P<0.001\right)$ was determined using unpaired $t$-tests. 


\section{Bovine Mammary Gland Involution}

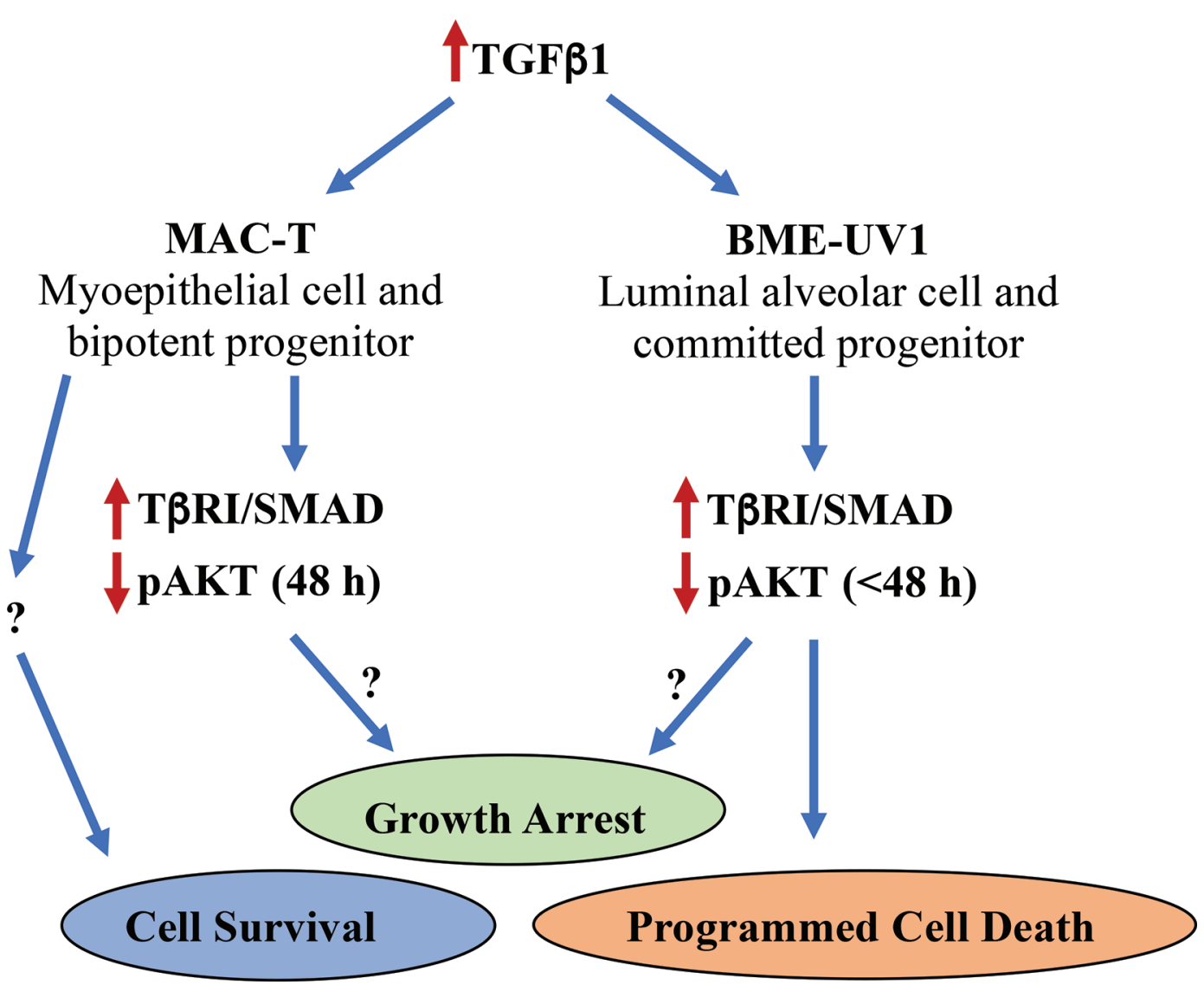

Figure 9. Proposed model of the effect of transforming growth factor $\beta 1$ (TGF $\beta 1$ ) in cell survival/death and cell growth in the different cell populations represented by MAC-T and BME-UV1 cell lines. At the onset of bovine mammary gland involution, TGF 31 levels increase and TGF $\beta 1$ binds to its receptor to activate downstream signaling. In luminal alveolar cells and committed progenitors (BME-UV1 cells), TGF $\beta 1$ activates T $\beta R I / S M A D$ signaling and temporarily reduces AKT activity, contributing to the induction of programmed cell death (PCD) and possibly (?) to growth arrest. In myoepithelial cells and bipotent progenitors (MAC-T cells), TGF $\beta 1$ activates T $\beta R I$, which facilitates a reduction in AKT activity, possibly resulting in growth arrest. Independent of T $\beta R I / S M A D$, TGF $\beta 1$ suppresses PCD through an unknown mechanism in MAC-T cells.

Charles Mitz and Mary Ellen Cybulski for their critical review of the manuscript. This project was funded by an NSERC grant (RGPIN-2017-3977) to AVP and an NSERC graduate scholarship to CAM. The authors have not stated any conflicts of interest.

\section{REFERENCES}

Arévalo Turrubiarte, M., M. Perruchot, L. Finot, F. Mayeur, and F. Dessauge. 2016. Phenotypic and functional characterization of two bovine mammary epithelial cell lines in 2D and 3D models. Am. J. Physiol. Cell Physiol. 310:C348-C356. https://doi.org/10.1152/ ajpcell.00261.2015.

Argetsinger, L. S., G. Campbell, X. Yang, B. Witthuhn, O. Silvennoinen, J. Ihle, and C. Carter-Su. 1993. Identification of JAK2 as a growth hormone receptor-associated tyrosine kinase. Cell 74:237244. https://doi.org/10.1016/0092-8674(93)90415-m.
Bauman, D. 1999. Bovine somatotropin and lactation: From basic science to commercial application. Domest. Anim. Endocrinol. 17:101-116. https://doi.org/10.1016/S0739-7240(99)00028-4.

Bouillet, P., L. Zhang, D. Huang, G. Webb, C. Bottema, P. Shore, H. Eyre, G. Sutherland, and J. Adams. 2001. Gene structure, alternative splicing, and chromosomal localization of pro-apoptotic Bcl-2 relative Bim. Mamm. Genome 12:163-168. https://doi.org/ 10.1007 /s003350010242.

Chapman, R. S., P. Lourenco, E. Tonner, D. Flint, S. Selbert, K Takeda, S. Akira, A. Clarke, and C. Watson. 1999. Suppression of epithelial apoptosis and delayed mammary gland involution in mice with a conditional knockout of Stat3. Genes Dev. 13:26042616. https://doi.org/10.1101/gad.13.19.2604.

Chen, C. C., S. Jeon, P. Bhaskar, V. Nogueira, D. Sundararajan, I. Tonic, Y. Park, and N. Hay. 2010. FoxOs inhibit mTORC1 and activate Akt by inducing the expression of Sestrin3 and Rictor. Dev. Cell 18:592-604. https://doi.org/10.1016/j.devcel.2010.03.008.

Cross, D. A., D. Alessi, P. Cohen, M. Andjelkovich, and B. Hemmings. 1995. Inhibition of glycogen synthase kinase-3 by insulin mediated by protein kinase B. Nature 378:785-789. https://doi.org/10.1038/ $378785 \mathrm{a} 0$. 
del Peso, L., M. González-García, C. Page, R. Herrera, and G. Nuñez. 1997. Interleukin-3-induced phosphorylation of BAD through the protein kinase Akt. Science 278:687-689. https://doi.org/10.1126/ science.278.5338.687.

Di, H. S., L. Wang, G. Wang, L. Zhou, and Y. Yang. 2012. The signaling mechanism of TGF- $\beta 1$ induced bovine mammary epithelial cell apoptosis. Asian-Australas. J. Anim. Sci. 25:304-310. https://doi .org/10.5713/ajas.2011.11251.

Etherton, T. D., and D. Bauman. 1998. Biology of somatotropin in growth and lactation of domestic animals. Physiol. Rev. 78:745761. https://doi.org/10.1152/physrev.1998.78.3.745.

Finot, L., E. Chanat, and F. Dessauge. 2019. Mammary epithelial cell lineages change during the cow's life. J. Mammary Gland Biol. Neoplasia 24:185-197. https://doi.org/10.1007/s10911-019-09427 $-1$.

Franke, T. F. 2008. PI3K/Akt: Getting it right matters. Oncogene 27:6473-6488. https://doi.org/10.1038/onc.2008.313.

Gajewska, M., and T. Motyl. 2004. IGF-binding proteins mediate TGF- $\beta 1$-induced apoptosis in bovine mammary epithelial BMEUV1 cells. Comp. Biochem. Physiol. C Toxicol. Pharmacol. 139:65-75. https://doi.org/10.1016/j.cca.2004.09.006.

Hans, F., and S. Dimitrov. 2001. Histone H3 phosphorylation and cell division. Oncogene 20:3021-3027. https://doi.org/10.1038/sj.onc .1204326 .

Herbertz, S., J. Sawyer, A. Stauber, I. Gueorguieva, K. Driscoll, S. Estrem, A. Cleverly, D. Desaiah, S. Guba, K. Benhadji, C. Slapak, and M. Lahn. 2015. Clinical development of galunisertib (LY2157299 monohydrate), a small molecule inhibitor of transforming growth factor-beta signaling pathway. Drug Des. Devel. Ther. 9:4479-4499. https://doi.org/10.2147/DDDT.S86621.

Huang, H., and D. Tindall. 2007. Dynamic FoxO transcription factors. J. Cell Sci. 120:2479-2487. https://doi.org/10.1242/jcs.001222.

Humphreys, R. C., B. Bierie, L. Zhao, R. Raz, D. Levy, and L. Hennighausen. 2002. Deletion of Stat3 blocks mammary gland involution and extends functional competence of the secretory epithelium in the absence of lactogenic stimuli. Endocrinology 143:3641-3650. https://doi.org/10.1210/en.2002-220224.

Hurley, W. L. 1989. Mammary gland function during involution. J. Dairy Sci. 72:1637-1646. https://doi.org/10.3168/jds.S0022 -0302(89) 79276-6.

Huynh, H. T., G. Robitaille, and J. Turner. 1991. Establishment of bovine mammary epithelial cells (MAC-T): An in vitro model for bovine lactation. Exp. Cell Res. 197:191-199. https://doi.org/10 .1016/0014-4827(91)90422-q.

ImageJ. 2017. Particle analysis. Accessed Dec. 6, 2017. https://imagej .net/Particle_Analysis.

Jedrzejczak, M., and I. Szatkowska. 2014. Bovine mammary epithelial cell cultures for the study of mammary gland functions. In Vitro Cell. Dev. Biol. Anim. 50:389-398. https://doi.org/10.1007/s11626 -013-9711-4.

Kolek, O., B. Gajkowska, M. Godlewski, and T. Motyl. 2003. Antiproliferative and apoptotic effect of TGF- $\beta 1$ in bovine mammary epithelial BME-UV1 cells. Comp. Biochem. Physiol. C Toxicol. Pharmacol. 134:417-430. https://doi.org/10.1016/s1532-0456(02)00249 -1 .

Lei, K., and R. Davis. 2003. JNK phosphorylation of Bim-related members of the Bcl2 family induces Bax-dependent apoptosis. Proc. Natl. Acad. Sci. USA 100:2432-2437. https://doi.org/10 $.1073 /$ pnas.0438011100.

Mitz, C. A., and A. Viloria-Petit. 2019. TGF-beta signalling in bovine mammary gland involution and a comparative assessment of MAC-T and BME-UV1 cells as in vitro models for its study. PeerJ 6:e6210. https://doi.org/10.7717/peerj.6210.
Pai, V., and N. Horseman. 2011. Mammary gland involution: events, regulation and influence on breast disease. Pages 247-284 in Endothelium and Epithelium: Composition, Functions and Pathology. J. Carrasco and M. Mota, ed. Nova Science Publishers, Cincinnati, $\mathrm{OH}$.

Plath, A., R. Einspanier, F. Peters, F. Sinowatz, and D. Schams. 1997. Expression of transforming growth factors alpha and beta- 1 messenger RNA in the bovine mammary gland during different stages of development and lactation. J. Endocrinol. 155:501-511. https:/ /doi.org/10.1677/joe.0.1550501.

Prêtre, V., and A. Wicki. 2018. Inhibition of Akt and other AGC kinases: A target for clinical cancer therapy? Semin. Cancer Biol. 48:70-77. https://doi.org/10.1016/j.semcancer.2017.04.011.

Ramesh, S., G. Wildey, and P. Howe. 2009. Transforming growth factor $\beta$ (TGF $\beta$ )-induced apoptosis: The rise and fall of Bim. Cell Cycle 8:11-17. https://doi.org/10.4161/cc.8.1.7291.

Singh, K., I. Vetharaniam, J. Dobson, M. Prewitz, K. Oden, R. Murney, M. Swanson, R. McDonald, H. Henderson, and K. Stelwagen. 2016. Cell survival signalling in the bovine mammary gland during the transition from lactation to involution. J. Dairy Sci. 99:75237543. https://doi.org/10.3168/jds.2015-10515.

Sreekumar, A., M. Toneff, E. Toh, K. Roarty, C. Creighton, G. Belka, D. Lee, J. Xu, L. A. Chodosh, J. A. S. Richards, and J. M. Rosen. 2017. WNT-mediated regulation of FOXO1 constitutes a critical axis maintaining pubertal mammary stem cell homeostasis. Dev. Cell 43:436-448.e6. https://doi.org/10.1016/j.devcel.2017.10.007.

Tang, L. Y., M. Heller, Z. Meng, L. Yu, Y. Tang, M. Zhou, and Y. Zhang. 2017. Transforming growth factor- $\beta$ (TGF- $\beta$ ) directly activates the JAK1-STAT3 axis to induce hepatic fibrosis in coordination with the SMAD pathway. J. Biol. Chem. 292:4302-4312. https://doi.org/10.1074/jbc.M116.773085.

Tucker, H. A. 2000. Hormones, mammary growth, and lactation: A 41-year perspective. J. Dairy Sci. 83:874-884. https://doi.org/10 .3168/jds.S0022-0302(00)74951-4.

Yang, Y., Y. Zhao, W. Liao, J. Yang, L. Wu, Z. Zheng, Y. Yu, W. Zhou, L. Li, J. Feng, H. Wang, and W. Zhu. 2009. Acetylation of FoxO1 activates Bim expression to induce apoptosis in response to histone deacetylase inhibitor depsipeptide treatment. Neoplasia 11:313-324. https://doi.org/10.1593/neo.81358.

Yi, J. Y., I. Shin, and C. Arteaga. 2005. Type I transforming growth factor beta receptor binds to and activates phosphatidylinositol 3-kinase. J. Biol. Chem. 280:10870-10876. https://doi.org/10 .1074/jbc.M413223200.

Zarzyńska, J., M. Gajewska, and T. Motyl. 2005. Effects of hormones and growth factors on TGF- $\beta 1$ expression in bovine mammary epithelial cells. J. Dairy Res. 72:39-48. https://doi.org/10.1017/ s0022029904000639.

Zarzyńska, J., and T. Motyl. 2005. Dissimilar effects of LY 294002 and PD 098059 in IGF-I- mediated inhibition of TGF-Beta1 expression and apoptosis in bovine mammary epithelial cells. J. Physiol. Pharmacol. 56:181-193.

Zavizion, B., M. van Duffelen, W. Schaeffer, and I. Politis. 1996. Establishment and characterization of a bovine mammary epithelial cell line with unique properties. In Vitro Cell. Dev. Biol. Anim. 32:138-148. https://doi.org/10.1007/bf02723679.

\section{ORCIDS}

C. A. Mitz @ https://orcid.org/0000-0003-2329-5852

A. M. Viloria-Petit (® https://orcid.org/0000-0003-4556-5251 